\title{
A tervezett magatartás elméletének alkalmazása a vállalkozói hajlandóság alakulásának magyarázatára
}

\begin{abstract}
A vállalkozási szándék a vállalkozóvá válás fontos mérföldköve. Nélküle nem ébred fel az igény az egyénben arra, hogy saját vállalkozást hozzon létre. A vállalkozási aktivitás ösztönzéséhez fontos lehet annak kiderítése, hogy milyen tényezők formálják a vállalkozási szándékot, és hogyan befolyásolható ezek alakulása. A cikkben Icek Ajzen tervezettmagatartás-elméletét teszteltük strukturális egyenletekkel, a GUESSS kutatási projekt adatbázisának felhasználásával. Több mint kétezer magyarországi főiskolai és egyetemi hallgató válaszai alapján igazoltuk a szubjektív normák-attitüdök-szándék-cselekvés okozati láncot. Eszerint a támogató szociális környezet pozitívan befolyásolja a vállalkozási szándékkal kapcsolatos attitüdöket. A szándék pedig erőteljesen befolyásolja a tényleges cselekvést. Ezentúl azt találtuk, hogy a szubjektív normák pozitív hatást gyakorolnak az észlelt magatartási kontrollra, amely viszont csupán elhanyagolható hatással van a szándékra. Mindez azt sejteti, hogy a gyorsan alakítható vállalkozói feltételek (például forrásbiztosítás) csak korlátozottan változtatják a vállalkozásindítási elképzeléseket. Journal of Economic Literature (JEL) kód: JEL: I21, I23.
\end{abstract}

A kis- és középvállalatok meghatározó szerepet töltenek be a munkahelyteremtés és a gazdasági teljesítmény szempontjából egyaránt (Carree-Thurik [2010]). Az Európai Unióban a foglalkoztatás 67 százalékáért és a gazdasági teljesítmény 57 százalékáért felelnek (Hope [2016]), Magyarországon a foglalkoztatásban betöltött szerepük az EUátlagnak megfelelö, hozzáadott értékük azonban alig több mint 40 százaléka a teljes vállalati kör hozzáadott értékének (KSH [2016]).

Éppen ezért nagyon fontos kérdés, hogyan ösztönözhető minél több vállalkozás létrejötte, és miként érhető el, hogy ezek minél nagyobb hozzáadott értéket tudjanak előállítani. A felsőfokú végzettséggel rendelkezők nagyobb arányban hozzák

* A kutatást az OTKA 109839 K projekt (A magyar fiatalok vállalkozásindítási elképzelései és ösztönzési lehetőségei) támogatta.

S. Gubik Andrea egyetemi docens, Miskolci Egyetem Gazdaságtudományi Kar.

Kása Rihárd tudományos főmunkatárs, Budapesti Gazdasági Egyetem Pénzügyi és Számviteli Kar.

Farkas Szilveszter föiskolai tanár, Budapesti Gazdasági Egyetem Pénzügyi és Számviteli Kar.

A kézirat első változata 2017. március 3-án érkezett szerkesztőségünkbe.

DOI: http://dx.doi.org/10.18414/KSZ.2018.1.74 
létre vállalkozásaikat magasabb hozzáadott értéket előállító ágazatokban (például csúcstechnológiai iparágakban), magasabb alaptőkével alapítják meg vállalkozásukat (Richert-Schiller [1994]-et idézi Lüthje-Franke [2002]), továbbá növekedésorientáltabbak (Schrör [2006], Autio [2005]). A felsőoktatásban részt vevő fiatalok vállalkozói szándékának ösztönzése és vállalkozói aktivitásuk fokozása ezért fontos gazdaságpolitikai kérdés. Jelen cikkben Ajzen tervezettmagatartás-elméletének a felhasználásával a GUESSS (Global University Entrepreneurial Spirit Students' Survey) projekt 2011-es adatbázisán keressük ennek a kérdéskörnek a legfontosabb összetevőit.

A tanulmányban először a vállalkozói hajlandósággal kapcsolatos szakirodalmat tekintjük át, majd ismertetjük a tesztelni kívánt modellt. A hipotézisek megfogalmazása után az adatbázist, az elemzésbe bevont változókat, valamint az alkalmazott módszertant mutatjuk be. Ezt követően strukturális egyenleteken alapuló modellt (SEM) használunk a hipotézisek tesztelésére. Végül a legfontosabb eredményeket foglaljuk össze és következtetéseinket fogalmazzuk meg.

\section{Szakirodalmi összefoglaló}

A vállalkozásösztönzésen belül kitüntetett figyelmet kap a fiatalok vállalkozóvá válása. Számos dokumentum elemzi a jelenlegi helyzetet és tesz gazdaságpolitikai javaslatokat, például az Entrepreneurship 2020 Action Plan (EC [2013]), a Youth Entrepreneurship in Europe: Values, Attitudes, Policies (Eurofound [2015]) és az Erasmus for Young Entrepeneurs (EC [2015]). Ezekben az anyagokban közös megállapítás, hogy a felsőoktatásban tanulókat komplex módon kell segíteni a legjobb gyakorlatok megismertetésével, a vállalkozási ismeretek oktatásának korszerüsítésével és a pénzügyi támogatások elérhetővé tételével. Fiatalokon az ENSZ a 15 és 24 éves életkor közöttieket érti, az Eurostat a 15 és 29 év közötti korosztályt, a GEM (Global Entrepreneurship Monitor) a 18-34 éveseket. Ugyan az egyetemi-föiskolai hallgatók csupán speciális részhalmazát képezik a fiatalok csoportjának, de vállalkozási szempontból igen meghatározó részét (magasabb hozzáadott értékü, növekedésorientáltabb vállalkozásokat indítanak), ezért munkánk során csak rájuk koncentrálunk, és csak a felsőoktatásban részt vevőkre terjesztjük ki a korosztály vizsgálatát.

Nehéz meghatározni, hogy mely területen lehet sikeresen növelni az életképes vállalkozások számát. Az oktatás szerepe nem vitatható, az alkalmazott megoldásai körül azonban már számos szakmai vita körvonalazódik. A hagyományos oktatási megoldások kevéssé ösztönzik a vállalkozói gondolkodást (EC [2008]), a sikeres vállalkozás elengedhetetlen feltételeinek tűnő készségek megszerzéséhez új megoldásokra, valódi vállalkozáson keresztül történő tanulásra van szükség (Szirmai-Csapó [2006], ImrehTóth [2015], Borsi-Dőry [2015]). Ugyanakkor empirikus eredmények arra utalnak, hogy a formális képzés továbbra is szignifikáns magyarázója a vállalkozási szándék alakulásának (S. Gubik [2013], Szerb-Lukovszki [2013]).

Az oktatás mellett a szakirodalom számos fontosnak tünő tényezőt sorol fel. Nemcsak abban térnek el az egyes kutatások, hogy milyen tényezőket hangsúlyoznak, hanem abban is, hogy mekkora jelentőséget tulajdonítanak az egyes tényezöknek. 
Az egyéni tulajdonságok közül különösen fontosnak tünik a kockázatvállalási hajlandóság, a függetlenség kialakítására való törekvés (Meager és szerzőtársai [2003]).

Számos cikk foglalkozik a társadalmi környezet szerepével a vállalkozási folyamatban. Autio-Wennberg [2010] kutatási eredményei szerint az egyén közösségének normái és attitüdjei jobban befolyásolják az egyén vállalkozói viselkedését, mint az egyén saját attitüdjei és érzékelt énhatékonysága (selfefficacy).

Meghatározó lehet továbbá a nemzeti kultúra szerepe, mint ahogy arra számos kutatás rávilágít. Ezek egyik csoportja a nemzeti kultúra egyéni jellemzőkre gyakorolt hatását vizsgálja (például Thurik-Dejardin [2012], Thomas-Mueller [2000]), másik része aggregált vállalkozói statisztikákkal hozza összefüggésbe az egyes kulturális dimenziókat (például Zhao és szerzőtársai [2012], Shane és szerzőtársai [1991]). A fentieken túl nyilvánvalóan nagy szerepe van a támogató rendszernek (hogyan lehet forrásokhoz jutni), a vállalkozásindításnak, a vállalkozási folyamatnak (milyen adminisztratív terhei vannak, milyen adóteherrel kell számolni stb.).

A szerteágazó irodalomban eligazodást jelenthetnek azok az összetett modellek, amelyek a fenti hatásokat (egyén, társadalom, intézményrendszer) egy komplex rendszerbe igyekszenek besüríteni. Ilyen modell például a szociális kognitív elmélet (Social Cognitive Theory - Bandura [1977], [1989]), a vállalkozási esemény modellje (Entrepreneurial Event - Shapero-Sokol [1982]) vagy a cikk alapjául választott tervezett magatartás elmélete elnevezésü modell is (Theory of Planned Behaviour - Ajzen [1991]).

Mindhárom modell kiemelt szerepet tulajdonít az egyén értékrendjének, attitűdjeinek, benyomásainak, beemeli a környezetet, a társadalom felöl érkező jeleket, és hangsúlyozza ezek egymásra hatását.

\section{A kutatás elméleti és módszertani keretei}

A GUESSS kutatás Ajzen [1991] tervezett magatartás elméleti keretein nyugszik. Vizsgálataink során ezt a modellt választottuk a szakirodalomban fellelhető komplex modellek közül. Az elmélet szerint az attitüdök, a szubjektív normák és az észlelt magatartási kontroll együttesen befolyásolják a vállalkozóvá válás szándékát, amely elvezet a tényleges cselekvéshez. Az 1. ábra Ajzen tervezettmagatartáselméletét mutatja.

Az Ajzen-modell egyik központi gondolata a szándék és a cselekvés megkülönböztetése. A komoly vállalkozói szándék még nem jelenti azt, hogy az adott cselekvés ténylegesen meg is valósul, azaz sor kerül a vállalkozásindításra. A szándék az attitüdök, a szubjektív normák és az észlelt magatartási kontroll függvénye. Komoly szándék nélkül nem várható tényleges cselekvés. Ugyanakkor a tényleges cselekvést befolyásolják olyan objektív tényezők, mint például a szükséges források, lehetőségek elérése (pénz, idő stb.), amelyek az adott szándék megvalósításához szükségesek. Ezt a tényezőt a modell aktuális magatartási kontrollnak nevezi (actual control), és Ajzen modelljének újabb változata tartalmazza csupán (Ajzen [2006a]).

A modell szerint a vállalkozásindításra irányuló attitűd és a vállalkozási szándék között pozitív irányú összefüggés van. Minél kedvezőbb az egyén vállalkozásindítással 
1. ábra

A vállalkozásindítási szándék tényezői

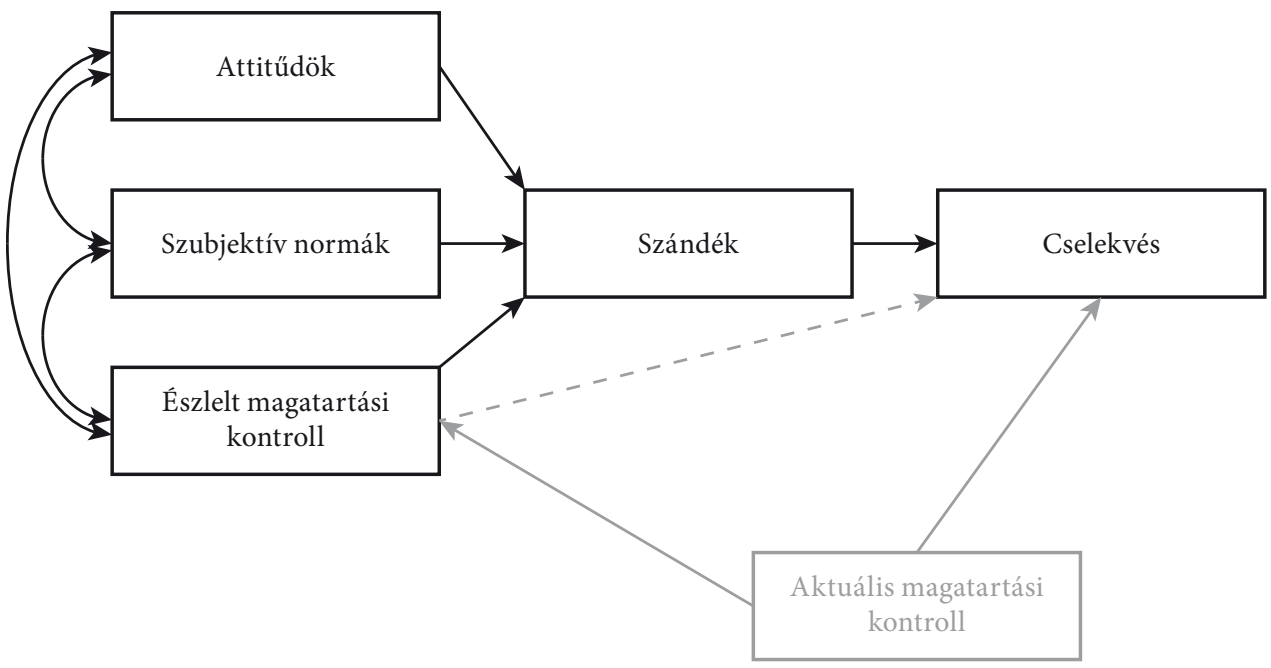

Forrás: Ajzen [2006a].

összefüggő beállítottsága, várhatóan annál nagyobb lesz a vállalkozásindítási szándéka is. A támogató szociális környezet, a társadalmi normák (szubjektív norma) is pozitívan hathatnak a vállalkozásindítási szándékra. Minél inkább úgy észleli az egyén, hogy környezete pozitívan viszonyul vállalkozásindítási elképzeléseihez, annál inkább várható, hogy szándékot mutat majd saját vállalkozás megvalósítására.

A harmadik tényező, az események feletti kontroll (észlelt magatartási kontroll) szintén közvetlenül befolyásolja a vállalkozásindítási szándékot, de a tényleges cselekvésre is hatást gyakorolhat. Az észlelt magatartási kontroll kétféle módon hat a szándékra és a cselekvésre. Egyrészt minél inkább úgy érzi az egyén, hogy képes kontrollálni az eseményeket, annál inkább szándékában állhat saját vállalkozási tevékenységbe fogni. Másrészt az énhatékonyság szintén pozitív irányba tolja a vállalkozási szándékot. Minél inkább úgy érzi az egyén, hogy birtokában áll a vállalkozásindításhoz szükséges képességeknek és tudásnak, annál inkább elképzelhetőnek tartja saját vállalkozásának beindítását. Azonos szándék mellett az észlelt kontroll eltérő mértéke eltérő kitartást és erőfeszítést követel az egyének részéről, így a cselekvés sikerességét közvetlenül befolyásolja (Ajzen [2006b]).

A szándékot befolyásoló tényezők egymással is összefüggnek, illetve az észlelt magatartási kontroll két dimenziója, a kontrollálhatóság és az énhatékonyság között is létezik kapcsolat. Ez a kapcsolat lehet egymást erősítő, de elképzelhető, hogy ellentétes irányú a hatás. Az egyén, aki úgy érzi, hogy rendelkezik a szükséges képességekkel és tapasztalatokkal, érezheti úgy is, hogy képes kontrollálni az eseményeket, de úgy is, hogy az események kicsúszhatnak a kezei közül.

Az Ajzen-modellt közel 6000 magyarországi hallgató mintáján S. Gubik [2013] tesztelte multinomiális logisztikus regresszió segítségével. Arra az eredményre jutott, hogy az észlelt magatartási kontroll, valamint az attitüdök egyaránt pozitív irányban 
befolyásolják a vállalkozásindítási szándékot, a szubjektív normák szerepét ugyanakkor nem tudta alátámasztani. A modell kiegészítése (nem, kor, képzési terület, egyetemi környezet hatása) növelte a modell magyarázó erejét.

Szintén multinomiális logisztikus regressziót alkalmazott Szerb-Lukovszki [2013], de saját modelljük tesztelését végezték el, amely az Ajzen-modellből mindössze az énhatékonyságot mérő változókat tartalmazta (ezeket ők Tudatosságnak, Innovációs készségnek és Kockázatkezelésnek nevezték el). Mindkét cikk felhívja a figyelmet a családi vállalkozói háttér befolyásoló erejére és az oktatás szerepére, ez utóbbit $S$. Gubik [2013] az igénybe vett kurzusok és erőforrások számával illesztette a modellbe, Szerb-Lukovszki [2013] pedig dichotóm változó formájában (vett-e részt vállalkozói kurzuson a hallgató - igen/nem), de az Ajzen-modellre vonatkozóan közös megállapításokat nem fogalmaznak meg.

Továbbá a fenti két munka nem tért ki a szándék és a tényleges cselekvés összefüggésének vizsgálatára, és ezeket a tényezőket nem is építette be magatartásikontrollmodelljébe. Jelen munka ezeket a kiegészítéseket megteszi.

Módszertani szempontból a multinomiális regresszió alkalmazása bevett megoldás a szakirodalomban a vállalkozásindítási szándék vizsgálata során, ezzel dolgozott Zellweger és szerzötársai [2011], Szerb-Márkus [2007] is. Erénye, hogy alacsony mérési szintü, nem normális eloszlású változók esetén is jól alkalmazható, ugyanakkor megbízhatóan csak az együttes magyarázó erő becslésében és a vizsgálatba bevont változók egyenkénti szignifikáns hatásáról győződtünk meg a segítségével.

Jelen cikkben a modell teszteléséhez strukturális egyenleteken alapuló modellt (SEM) használunk. Strukturális egyenletek alkalmazására találunk példát a vállalkozási szakirodalomban. Ilyen elemzést végzett például Kolvereid [1996], Plant-Ren [2010], de a magyarországi helyzet elemzésére ilyen módszertannal eddig nem került sor.

Ez a módszer kiválóan alkalmas egy modell hipotéziseinek tesztelésére, egyszerre három kritérium alapján: a) illeszkedésvizsgálat alapján (azaz hogy a becsült kovarianciamátrix megegyezik-e a megfigyelt kovarianciamátrixszal); $b$ ) validitás és megbízhatóság elemzése alapján; c) szignifikáns és érdemi strukturális kapcsolatok alapján.

\section{Hipotézisek}

Az Ajzen-modell az emberi viselkedést három változó segítségével igyekszik leírni: az egyén viselkedését az egyénnek a viselkedés lehetséges kimenetelére vonatkozó elképzelései és ezen kimenetelek értékelése (behavioral beliefs), mások várakozásaira vonatkozó elképzelései, valamint az ezeknek megfelelni vágyás (normative beliefs) és az adott viselkedést elősegítő vagy gátló tényezők meglétére és azok erősségére vonatkozó elképzelései (control beliefs) vezérlik (Ajzen [2006b]). Ezen vélekedések eredménye, megtestesülése az attitüd, a szubjektív norma és az észlelt magatartási kontroll. A modell bármilyen viselkedés előrejelzésében segítségünkre lehet, így a vállalkozásindítási hajlandóság terén is. Összehasonlító vizsgálatokat is találunk a szakirodalomban, ahol Ajzen modelljét más modellekkel vetik össze, és alkalmasnak találják 
a vállalkozói hajlandóság és aktivitás témakörben történő felhasználásra (Krueger és szerzőtársai [2000]). A modellt ezért a magyarországi hallgatók vállalkozásindítási szándékának tesztelésére is megfelelőnek tartjuk.

1. HIPOTÉZIS • Az Ajzen-modell jól illeszkedik a GUESSS kutatás adataira, így alkalmazható a magyarországi hallgatók vállalkozási szándékának és aktivitásának vizsgálatára.

A hipotézisek megfogalmazásakor az aktuális magatartási kontrollal kiegészített Ajzen-modellből indultunk ki (Ajzen [2006a]). A szakirodalomban konszenzus van az attitüdök szerepére vonatkozóan, amely szerint a vállalkozásindításra irányuló kedvező attitűd pozitív irányban befolyásolja a vállalkozásindítási szándékot (Autio és szerzőtársai [2001], Krueger és szerzőtársai [2000], Nishimura-Tristán [2011], LiñánChen [2009], S. Gubik [2013]). Ráadásul az attitűdök és a szándék közötti kapcsolat bizonyul a legerősebbnek számos empirikus vizsgálat alkalmával a modell egyes elemei közül (lásd például Liñán-Chen [2009]).

2. ніротÉZIs • Minél kedvezőbb az egyén vállalkozásindítással összefüggő attitűdje, annál inkább szándékot mutat saját vállalkozás indítására.

A szubjektív norma szignifikáns hatását korábbi kutatások nem tudták egyértelmüen megerősíteni. Engle és szerzőtársai [2010] 12 országra kiterjedő kutatásában a modell változói közül egyedül a szubjektív norma bizonyult szignifikáns előrejelzőnek valamennyi vizsgált országban. Hasonló kapcsolatot tárt fel a szándék és a norma között Ozaralli-Rivenburgh [2016], valamint Kautonen és szerzőtársai [2015] is. Más kutatások azonban (például Autio és szerzőtársai [2001], Krueger és szerzőtársai [2000], Nishimura-Tristán [2011], Liñán-Chen [2009], S. Gubik [2013]) nem tudták ezt a szignifikáns összefüggést kimutatni a norma és a szándék között.

A kapott eredmények azt sugallják, hogy a támogató környezet nem lényegi befolyásoló tényezője a vállalkozási szándéknak, ami azonban ellentmond a várakozásoknak és a logikai okfejtésnek. Ugyanakkor a modellváltozók közötti korrelációs kapcsolatokra számos kutatás felhívja a figyelmet. Nishimura-Tristán [2011] kiemeli, hogy a lineáris korrelációs együtthatók szignifikáns volta ellenére a logisztikus regressziós modellben a szubjektív norma már nem képes érdemi hányadot magyarázni a vállalkozói szándék alakulásában. Ez arra utalhat, hogy a szubjektív norma nem közvetlenül fejti ki hatását a szándékra, hanem a vállalkozásindításra irányuló attitűdök és az észlelt magatartási kontroll alakításán keresztül befolyásolja a vállalkozói elképzeléseket. Autio és szerzötársai [2001] az észlelt magatartási kontroll esetén talált szignifikáns összefüggést a normával, Liñán-Chen [2009] pedig strukturális egyenletek alkalmazásával igazolta a szubjektív normának mind az attitüdökre, mind pedig az észlelt magatartási kontrollra gyakorolt hatását Spanyolország és Tajvan esetében (az elemzések a GEM adatbázisán alapulnak).

A fentiek ismeretében fogalmazzuk meg a 3. hipotézist, fenntartva azt a megérzést, hogy a három, az eredeti Ajzen [2006b] modellben okként beillesztett változó (attitüdök, szubjektív normák és észlelt magatartási kontroll) nem feltétlenül független egymástól, ilyen módon a közöttük kölcsönösen meglévő kovarianciákat is 
fenntartásokkal kell kezelni. Úgy feltételezzük, hogy a szubjektív normák befolyásolják az attitüdöket és az észlelt magatartási kontrollt is, ebben az esetben viszont a kovarianciák szerepeltetése nem helyes.

3.A нIPотÉZIS • A szubjektív norma pozitív irányban befolyásolja az attitűdöket.

3.в ніротÉZIS • A szubjektív norma pozitív irányban befolyásolja az észlelt magatartási kontrollt.

Az észlelt magatartási kontroll vállalkozásindítási szándékra gyakorolt pozitív hatását számos alkalommal bizonyították (lásd például Autio és szerzötársai [2001], Krueger és szerzötársai [2000], Nishimura-Tristán [2011], Liñán-Chen [2009], Kautonen és szerzőtársai [2015]), már a magyarországi adatbázisra vonatkozóan is rendelkezünk ilyen irányú eredményekkel (S. Gubik [2013], [2016]).

4. HIPOTÉZIS • Az észlelt magatartási kontroll pozitív irányú szignifikáns hatással van a vállalkozásindítási szándékra.

Végül a modell utolsó alkotóeleme az aktuális magatartási kontroll, amelyet az elemzések sok esetben szervesen nem tartalmaznak (Kautonen és szerzőtársai [2015], LiñánChen [2009], Autio és szerzőtársai [2001]). Ennek részben az az oka, hogy ez a változó nem volt az eredeti modell alkotóeleme, csupán 2006 óta publikálja a szerző ezt a verziót (Ajzen [2006b]). A magyarországi mintán kibővített modell tesztelése eddig nem történt meg. Az aktuális magatartási kontroll a modell szerint közvetlenül hat a cselekvésre, valamint közvetetten az észlelt magatartási kontrollon keresztül.

5.A ніроте́ZIS • Az aktuális magatartási kontroll pozitív irányú szignifikáns hatással van a vállalkozói aktivitásra.

5.в ніротÉZIS - Az aktuális magatartási kontroll pozitív irányú szignifikáns hatással van az észlelt magatartási kontrollra.

\section{Adatbázis és módszertan}

A GUESSS (Global University Entrepreneurial Spirit Students' Survey) ${ }^{1}$ egyetemisták megkérdezésével a hallgatók vállalkozásindítással kapcsolatos elképzeléseit és vállalkozási tevékenységét vizsgálja. A kutatás legfontosabb célja, hogy azonosítsa azokat az egyéni motívumokat, személyes háttérbeli jellemzőket (családi háttér) és intézményi tényezőket (felsőoktatási környezet), amelyek a vállalkozóvá válási folyamatot érdemben befolyásolhatják.

$\mathrm{Az}$ adatfelvételekre általában kétévente kerül sor. Az első lekérdezés 2003-ban történt, ekkor még csak két ország részvételével. A vizsgálat alapjául szolgáló

\footnotetext{
${ }^{1}$ A kutatási projekt vezető intézménye, a St. Gallen-i Egyetem munkatársai állították össze a nemzetközi és az egyes országok adatbázisait, és küldték meg az országokat képviselő csoportoknak, akik elkészítették országjelentéseiket, és önálló tudományos kutatásokat folytatnak. Szintén ők állították össze a kérdőívet, koordinálták az egyes országokat képviselő csoportok tevékenységét, a kérdőívek fordítását az adott ország nyelvére, valamint az elektronikus kérdezést. A kutatási projekt honlapja: http://guesssurvey.org.
} 


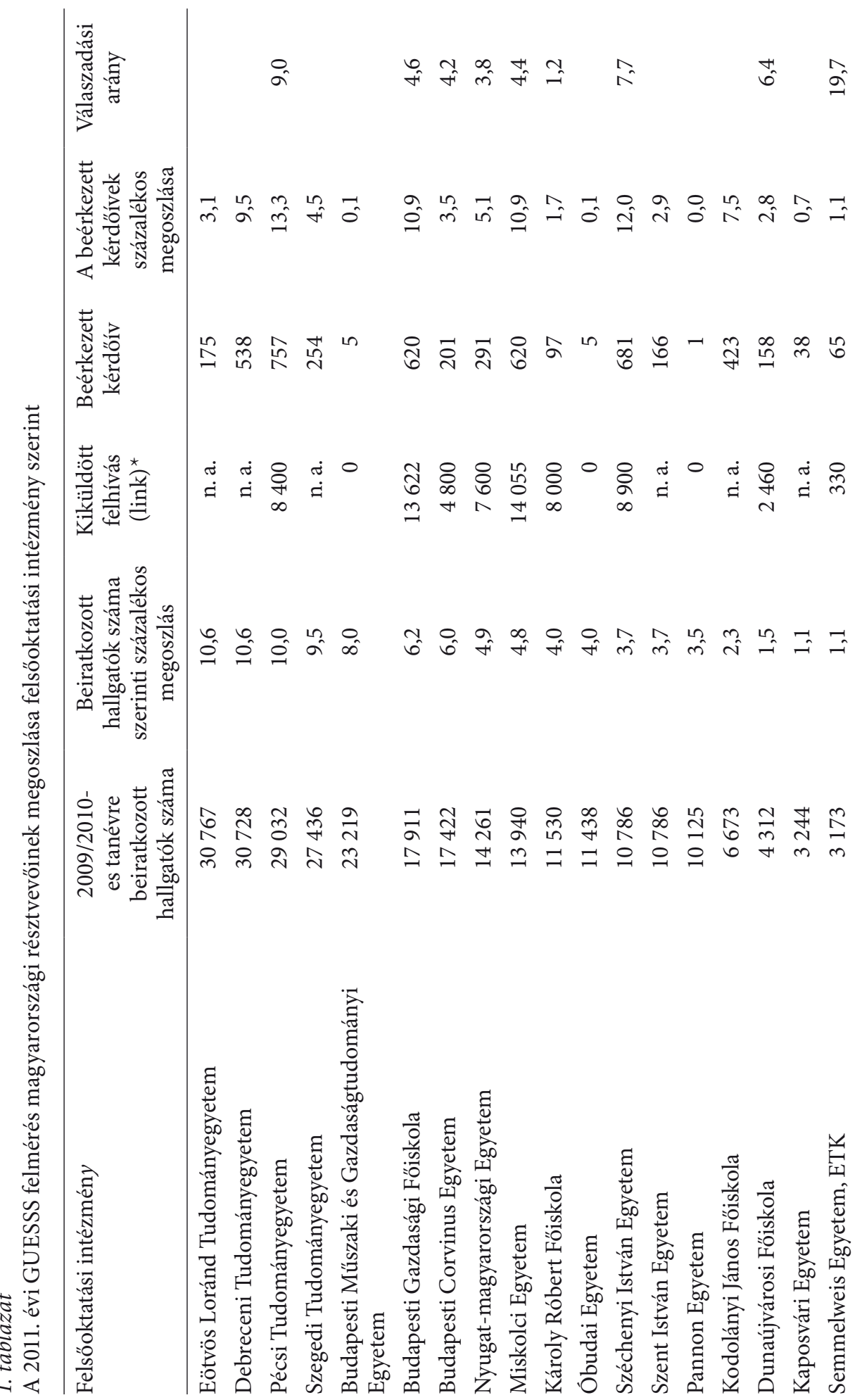




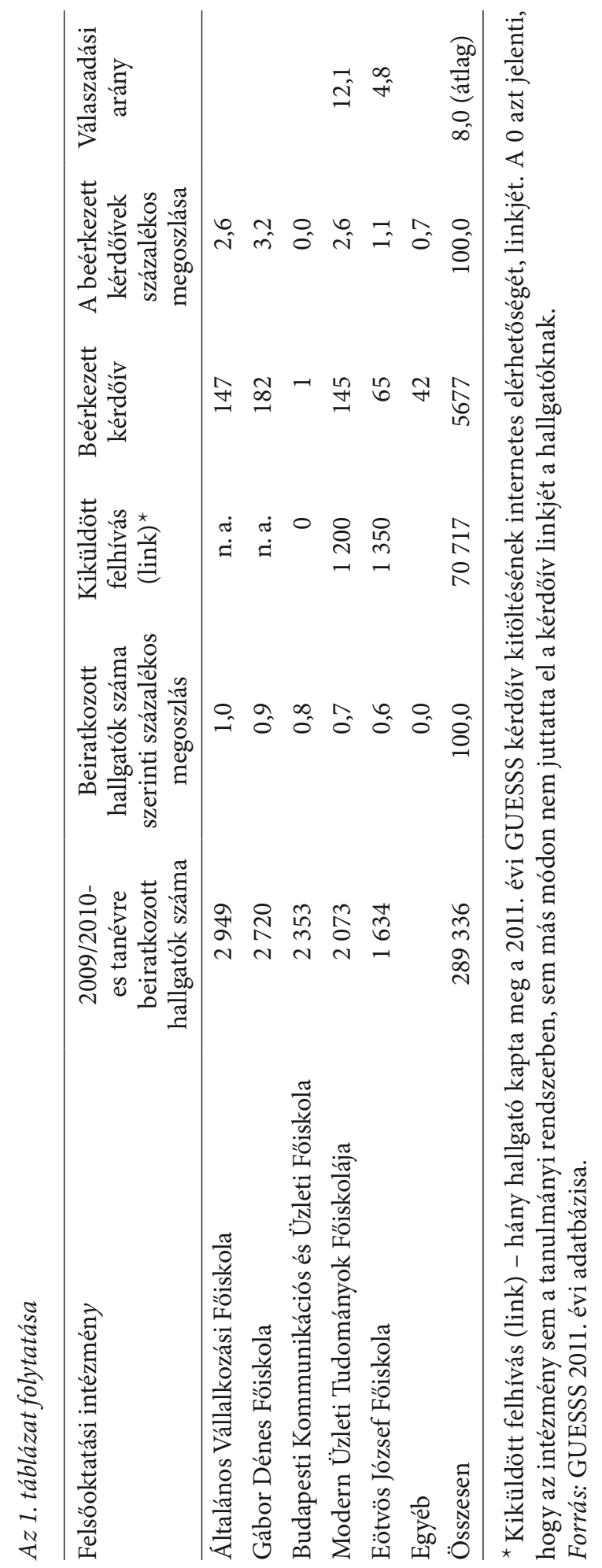


2011-es adatbázis 26 ország 93265 hallgatójának válaszait tartalmazza, köztük 5677 magyar hallgató válaszát.

Az 1. táblázat a magyarországi résztvevők megoszlását mutatja a válaszadók felsőoktatási intézménye szerint.

A kutatás során arra törekedtünk, hogy a kérdöívet eljuttassuk minden felsőoktatási intézménybe, ahol a hallgatói létszám elérte az ezer főt. A felhívás a hallgatói tanulmányi rendszereken (Neptun, ETR) és/vagy a közösségi portálokon jutott el a hallgatókhoz. A kiküldött felhívásoknak (ahol erre vonatkozóan rendelkezésre állt adat) átlagosan 8 százalékában kaptunk választ.

A válaszadók 43,8 százaléka gazdasági/üzleti területen tanul, 36 százalékuk természettudományi, további 19,4 százalékuk pedig társadalomtudományi területen folytat tanulmányokat. A válaszadók túlnyomó többsége (85,2 százalék) alapképzésben vesz részt. Ettől elmaradó a mintába került mesterhallgatók aránya (13,4 százalék). Mindöszsze 62 doktorandusz-, 13 mester- és 7 posztdoktori képzésben részt vevő hallgató töltötte ki a kérdőívet. A mintába nagyobb arányban (59,4 százalékban) kerültek nők. A férfinő összetétel hủen tükrözi a magyarországi felsőoktatás nemek szerinti összetételét. A válaszadók átlagos kora 25 év, 32,2 százalékuk az 1990-es években született, azaz a kérdőív kitöltésekor még nem töltötte be a 22. életévét. Az 1980 után születettek, tehát a 30. életévüket még be nem töltött hallgatók alkotják a minta 8 százalékát. A megkérdezett hallgatók közül 135-en számoltak be arról, hogy saját vállalkozással rendelkeznek. ${ }^{2}$

\section{A felhasznált változók}

A kérdőív lehetőséget ad mind a modell tényezőinek, mind pedig az azokra ható tényezőknek a vizsgálatára. A fogalmak operacionalizálása során a szakirodalomra hagyatkoztunk, maga a kérdőív is a bevett mérési módszereknek megfelelő kérdéseket tartalmazta. A következőkben bemutatjuk az alkalmazott változókat.

VÁLLALKOZÁSI SZÁNDÉK (INT) • Gondoltál-e már komolyan arra, hogy saját vállalkozást indíts? (8. kérdés) [Soha / Esetlegesen, néha / Újra meg újra (ismétlődően) / Viszonylag konkrétan / Határozottan döntöttem egy vállalkozás alapításáról / Konkrét ütemtervvel rendelkezem, hogy mikor, milyen lépéseket tegyek az alapításért / Már elkezdtem a megvalósítást / Az általam alapított vállalat alkalmazottja vagyok / Egy vállalatnál többet alapítottam, és legalább egyben aktív szerepet töltök be.]

АттітÜ Döк (Атт) • Kérjük, jelöld be, hogy mennyire értesz egyet az alábbi állitásokkal! (9. kérdés) [A vállalkozóvá válás számomra több előnyt jelent, mint hátrányt / A vállalkozói karrier számomra vonzó / Ha lenne lehetőségem, vállalkozó lennék / Vállalkozónak lenni számomra nagy megelégedettséget jelentene. (1-től 7-ig terjedő Likert-skála)].

\footnotetext{
2 A 2011-es magyar GUESSS adatbázis részletes bemutatását lásd http://www.guesssurvey.org/ resources/nat_2011/GUESSS2011-National-report-Hungary_2.pdf.
} 
SzubjeKtív NORмáк (suв) • Ha vállalkozó lennél, mit szólnának, hogyan vélekednének erröl az emberek a környezetedben? (10. kérdés) [Szülők, családtagok / Barátok, diáktársak / Számomra fontos emberek. (1-től 7-ig terjedő Likert-skála.)]

Kérjük, jelöld meg, hogy mennyire adsz az alábbi személyek véleményére! (11. kérdés) [Szülők, családtagok / Barátok, diáktársak / Számomra fontos emberek. (1-től 7-ig terjedő Likert-skála.)]

Kérjük, jelöld meg, hogy mennyire értesz egyet az egyetemre vonatkozó alábbi megállapitásokkal! (2.6. kérdés) [Az egyetem által nyújtott szolgáltatás ...növelte a vállalkozói attitűdök, értékek és motivációk megértését / ...növelte a vállalkozásindításhoz szükséges tevékenységek megértését / ...fejlesztette a vállalkozásindítással kapcsolatos gyakorlati ismereteimet / ...fejlesztette kapcsolatépítő képességemet / ... fejlesztette a lehetőségfelismerő képességemet / Az egyetemen a vállalkozóvá váláshoz kedvező környezet és lehetőségek vannak / Az egyetemen sok vállalkozói gondolkodású, beállítottságú társat találtam / A vállalkozói előadások, tréningek amelyeken részt vettél, elsősorban tudásátadók voltak (1), vagy tudtál dolgozni saját vállalkozási ötleteden (7)? (1-től 7-ig terjedő Likert-skála.)]

ÉSZlelt MAGATARTÁsi KONTROLL (PER) • Kérjük, jelöld meg, hogy mennyire értesz egyet az alábbi állitásokkal! (12. kérdés) [Általában képes vagyok meghatározni, hogy mi történjen az életemben / Általában képes vagyok védeni saját érdekeimet / Amikor terveket készítek, majdnem biztos vagyok abban, hogy elvégzem azokat / Annak érdekében, hogy a terveim beváljanak, gondoskodom arról, hogy az én elképzeléseim összhangban legyenek azoknak az embereknek az elképzeléseivel, akiknek hatalma van fölöttem / Életemet elsősorban más, erős egyéniségek irányítják / Ha megkapok valamit, amit szeretnék, az azért van, mert szerencsés vagyok / Nem mindig okos dolog hosszú távra terveznem, mert sok dolog válhat a jó vagy rossz szerencse kérdésévé / Sokszor úgy találom, hogy aminek meg kell történnie, az meg fog történni / Úgy érzem, hogy ami az életemben történik, azt gyakran mások befolyásolják, határozzák meg. (1-től 7-ig terjedő Likert-skála.)]

Kérjük, jelöld meg, hogy mennyire vagy biztos az alábbi szerepek, feladatok végrehajtásában! (13. kérdés) [Célok kijelölése és megvalósítása / Célokhoz igazított időbeosztás / Döntéshozatal bizonytalanság és kockázat mellett / Felelősségvállalás az ötletekért és döntésekért / Kockázat és bizonytalanság csökkentése / Pénzügyi elemzés készítése / Saját vállalat indítása / Saját vállalkozásomat sikeressé teszem / Számított kockázatok figyelembevétele / Új ötletek kitalálása / Új termékek és szolgáltatások fejlesztése. (1-től 7-ig terjedő Likert-skála)]

AktuÁlis Magatartási KONTROLL (ACT) • Kérjük, határozd meg, hogy az alábbiak mennyire akadályozzák üzleti vállalkozásod alapitását! (13.12. kérdés) [Pénzügyi források elérhetősége (hitel és saját tőke) / Jogszabályok (szabályok és rendeletek) / Jó üzleti ötlet hiánya / Szükséges készségek és képességek esetleges hiánya / Szükséges technikai ismeretek hiánya / Vállalkozóként túl sokat kellene dolgozni / Pénzügyi kockázatok / Ügyfél-, vásárlói kapcsolatok hiánya / Általános kedvezőtlen gazdasági környezet. (1-től 7-ig terjedő Likert-skála)]. 
CSELEKVÉs (вен) • Milyen lépéseket tettél saját vállalkozások alapitása érdekében? (13.1. kérdés) [Eddig még semmit / Első üzleti ötletek átgondolása / Üzleti terv összeállítása / Piaci lehetőségek meghatározása / Lehetséges társak keresése (például diáktárak) / Eszközök beszerzése / Termékfejlesztésen dolgozol / Találkozó, megbeszélés lehetséges fogyasztókkal / Pénzügyi szolgáltatók (bankok) megkeresése az alapításhoz szükséges pénz biztosításához / Már meghatároztad az alapítás időpontját.]

\section{Alkalmazott módszertan}

A hipotézisek teszteléséhez első lépésként a modell faktorait kell előállítanunk az adatbázis változóiból. Ehhez exploratív faktoranalízist (EFA) használunk Kaiser-féle normalizálással és varimax rotálással. Az eredmények helyességének ellenőrzését és verifikálását, valamint a faktormodell illeszkedését konfirmatív faktoranalízissel (CFA) végezzük el. Az így elóállított faktorokból strukturális egyenleteken alapuló modellezéssel (SEM) kauzális útmodelleket készítünk, amelyek megfelelnek Ajzen modelljének.

Annak érdekében, hogy a hipotéziseinket megfelelően tesztelni tudjuk, az Ajzenmodellek többféle verzióját is fel kell építenünk SEM modellként. Mivel az eredeti modellben Ajzen [2006a] a három változó függetlenségét feltételezte, és közéjük kovarianciákat illesztett, így elsőként ezt a modellt építjük fel. Eredetileg ebben még nem szerepelt az aktuális magatartási kontroll. Itt tehát az attitüdök (2. HIPOTÉZIs), a szubjektív normák és az észlelt magatartási kontroll (4. ніротÉzIs) együtt, de egymással nem összefüggve határozzák meg a szándékot.

A második modellvariáció bevezeti, hogy e három változó összefügg egymással oly módon, hogy a szubjektív normák közvetlenül befolyásolják az attitűdöket (3.A нIPOTÉZIS) és az észlelt magatartási kontrollt is (3.в ніротÉZIS), és ezeken keresztül közvetetten a szándékot is (2., illetve 4. HIPOTÉZIs).

A harmadik SEM-variánsba beillesztjük az aktuális magatartási kontrollt is, ilyen módon a fentiekkel együtt az 5.A és az 5.в нIротÉzIs is ellenőrizhető.

A hipotézisek tesztelését a SEM modellek standard $\beta$ paramétereinek értékével és szignifikanciájuk ellenőrzésével végezzük.

\section{Eredmények}

A kérdőívből kapott válaszok (az összes szisztematikus vagy egyéb ok miatt hiányzó választ tartalmazó egyed kihagyása után $n=2204$ ) alkalmazhatóvá tételéhez elöször exploratív faktoranalízist (EFA) használtunk, varimax rotációs eljárással és Kaiserféle normalizálással, hogy kinyerjük az adatbázisból az Ajzen [2006a] modelljének előállításához szükséges látens változókat. Ehhez a GUESSS kérdőiv 2. táblázatban jelölt kérdéseinek változóit használtuk fel. Az eljárás iterációi során némely előzetesen bevont változó az alacsony szintü belső konzisztencia miatt nem bizonyult szignifikánsnak a modellben, ezért ezeket kizártuk a további eljárásokból. A táblázat a szignifikáns változók végleges faktorsúlyainak terjedelmét is bemutatja. 
2. táblázat

Az exploratív faktorelemzés rotált faktormátrixa

\begin{tabular}{lcc}
\hline Faktor & Vonatkozó kérdések $^{*}$ & \begin{tabular}{c} 
Faktorsúly-terjedelem $^{\text {(abszolút értékben) }}$ \\
\hline Attitűdök (ATT)
\end{tabular} \\
Szubjektív normák (sUB) & 9. & $0,871-0,800$ \\
Észlelt magatartási kontroll (PER) & $10 ., 11 ., 2.6$. & $0,848-0,636$ \\
Aktuális magatartási kontroll (ACT) & $12 ., 13.0$. & $0,869-0,858$ \\
Cselekvés (BEH) & 13.12. & $0,912-0,736$ \\
\hline
\end{tabular}

${ }^{*}$ Ebben az oszlopban megadjuk a faktorokhoz kapcsolt kérdések sorszámát.

Mivel a vállalkozási szándék (INT) faktor egyetlen megfigyelt változót tartalmaz, így az értelemszerűen nem képezi részét a faktoranalízisnek, önmagában kerül felhasználásra a modellben. Az exploratív faktoranalízis során a 32 megfigyelt változót 5 látens faktorral ki tudjuk fejezni (lásd 2. táblázat). A redukció hatékonyságának és a kauzális modell illeszkedésének ellenőrzésére konfirmatív fakoranalízist (CFA) használunk Jöreskog [1969] ajánlása szerint. A legjobban illeszkedő modell megtalálása érdekében egymás után számos iterációt hajtottunk végre, jelen cikkben csak a legutolsó, legjobban illeszkedő, szignifikáns modellt mutatjuk be. A modell interpretálása szempontjából a szakirodalomban ajánlott teszteket elvégeztük, különös tekintettel a modell megbízhatóságának elemzésére, a konvergens és diszkrimináns validitás és a modell illeszkedésének tesztelésére.

\section{A megbízhatóság elemzése}

Az iterációk során számos modellstruktúrát megvizsgáltunk, a legjobban illeszkedő a mért 43 változó közül 32 változót tartalmazott. Az inkonzisztens mért változók elhagyásával a modell belső konzisztenciája jelentősen javult, a legkisebb Cronbachféle $\alpha$ értéke 0,756, ami még mindig a kívánatos érték felett van (Cronbach [1951]).

3. táblázat

Megbízhatóságelemzés

\begin{tabular}{lccccc}
\hline Faktor & $\begin{array}{c}\text { Modellbe } \\
\text { került (és mért) } \\
\text { változók száma }\end{array}$ & $\begin{array}{c}\text { Cronbach- } \\
\text { féle } \alpha\end{array}$ & $\begin{array}{c}\text { KMO- } \\
\text { teszt }\end{array}$ & $\begin{array}{c}\text { Bartlett-féle } \\
\text { szignifikancia }\end{array}$ & TVE \\
\hline Cselekvés & $10(10)$ & 0,996 & & & \\
Aktuális magatartási kontroll & $9(9)$ & 0,976 & & & \\
Szubjektív normák & $7(8)$ & 0,887 & 0,963 & 0,000 & 82,939 \\
Attitüdök & $4(4)$ & 0,938 & & & \\
Észlelt magatartási kontroll & $2(12)$ & 0,756 & & & \\
\hline
\end{tabular}


Ellenőriztük a változókészlet faktorálhatóságát is Kaiser-Meier-Olkin-mutatóval $(\mathrm{KMO}=0,900)$. A Bartlett-féle szférikus próbateszt is szignifikáns, ami szintén a változókészlet alkalmasságát jelzi, illetve az összes kifejezett variancia aránya (TVE) is megfelelően magas (Snedecor-Cochran [1989]). Ezek alapján a változókészlet megbízhatósága kétségtelen.

Az észlelt magatartási kontroll esetén a kérdőívben szereplő 12 változóból mindössze 2 került bele a modellbe (számított kockázatok figyelembevétele; döntéshozatal bizonytalanság és kockázat mellett). Fel kell ezért hívjuk a figyelmet arra, hogy ezen tényező Ajzen-modell szerinti teljes jelentéstartományát nem tudtuk lefedni.

\section{Validitás}

Ahhoz, hogy a faktormodellünk interpretálható legyen, fontos az érvényesség (validitás) megállapítása. Ezt két lépésben tettük meg: a konvergens validitás és a diszkrimináns validitás ellenőrzésével (Carmines-Zeller [1979]). A kompozit megbízhatóság (CR) és az átlagos kifejezett variancia (AVE) esetében a szakirodalomban megszokott küszöbértékek alapján minősítettük a modellt: $\mathrm{CR}>0,7$; CR $>$ AVE; AVE $>0,5$ (Hair és szerzötársai [2010]), illetve az összes standardizált faktorsúly meghaladja a 0,5-es értéket (Fornell-Larcker [1981]). Minden konstrukció tekintetében teljesülnek a konvergens validitás feltételei, ahogy ez a 4. táblázatban látható.

\section{4. táblázat}

A konvergens validitás mérőszámai

\begin{tabular}{lccc}
\hline & CR & AVE & Faktorsúlyok terjedelme (abszolút értékben) \\
\hline Aktuális magatartási kontroll & 0,975 & 0,815 & $0,912-0,736$ \\
Attitüdök & 0,934 & 0,780 & $0,871-0,800$ \\
Szubjektív normák & 0,878 & 0,511 & $0,848-0,636$ \\
Észlelt magatartási kontroll & 0,757 & 0,610 & $0,869-0,858$ \\
Cselekvés & 0,995 & 0,957 & $0,981-0,903$ \\
\hline
\end{tabular}

Fornell-Larcker [1981] lefektette a diszkrimináns validitás követelményeit is: a) adott faktor kifejezett átlagos varianciájának gyöke meghaladja a faktor és az összes többi faktor közötti korrelációs együtthatót; $b$ ) ha MSV $<$ AVE és $c$ ) ha ASV $<$ AVE minden egyes faktor esetén (MSV: maximum megosztott variancia; AVE: a faktorok által kifejezett átlagos variancia; ASV: átlagos megosztott variancia). Az 5. táblázatban feltüntettük a diszkrimináns validitás mérőszámait. Látható, hogy minden faktor esetében teljesülnek a követelmények.

Fentieken túl a modell illeszkedéséről is meg kell győződnünk, ehhez minden konstrukció mindhárom típusú illeszkedésvizsgálatának (abszolút illeszkedés, inkrementális illeszkedés és parszinomiális illeszkedés) tesztjeit el kell végezni mindaddig, amíg a tesztértékek javulnak. Ha e javulás már nem számottevő, akkor elértünk a legjobb 
5. táblázat

A diszkrimináns validitás mérőszámai*

\begin{tabular}{lccccc}
\hline & $\begin{array}{c}\text { Aktuális } \\
\text { magatartási } \\
\text { kontroll }\end{array}$ & Attitüdök & $\begin{array}{c}\text { Szubjektív } \\
\text { normák }\end{array}$ & $\begin{array}{c}\text { Észlelt } \\
\text { magatartási } \\
\text { kontroll }\end{array}$ & Cselekvés \\
\hline Aktuális magatartási kontroll & $(0,903)$ & $-0,549$ & $-0,071$ & $-0,215$ & $-0,386$ \\
Attitüdök & & $(0,883)$ & 0,244 & 0,347 & 0,130 \\
Szubjektív normák & & $(0,715)$ & 0,324 & $-0,001$ \\
Észlelt magatartási kontroll & & & & $(0,781)$ & 0,087 \\
Cselekvés & & & & & $0,978)$ \\
\hline AVE & 0,815 & 0,780 & 0,511 & 0,610 & 0,957 \\
MSV & 0,301 & 0,301 & 0,105 & 0,120 & 0,149 \\
ASV & 0,125 & 0,125 & 0,042 & 0,070 & 0,043 \\
\hline
\end{tabular}

* Zárójelben az AVE-értékek négyzetgyökei.

konstrukcióig. (Jelen tanulmányban csak a legjobban illeszkedő, végső modell tesztjeit közöljük.) A mutatók küszöbértékeinek meghatározásához a szakirodalomban elfogadott szigorúbb értékeket vesszük alapul, mint Schreiber és szerzötársai [2006], Wheaton és szerzőtársai [1977], Tabachnick-Fidell [2007] és Mulaik és szerzőtársai [1989].

Ebben a tekintetben a modell eredményei kielégítik az illeszkedési kritériumokat, ahogyan azt a 6. táblázat mutatja. Bár a modell által nem magyarázott varianciahányad mutatója (root mean square residual, RMSR) kissé magas, de még mindig az elfogadható tartományban van, ahogyan arról Tabachnick-Fidell [2007] érvel.

6. táblázat

A modell illeszkedésének mérőszámai

\begin{tabular}{lccc}
\hline Statisztika & Érték & Küszöb & Eredmény \\
\hline ABSzOLÚT ILLESZKEDÉs & & & \\
GFI (goodness of fit index) & 0,919 & $>0,8$ & jó \\
RMSR (root mean square residual) & 0,106 & $<0,08$ & mérsékelt \\
RMSEA (root mean square error of approximation) & 0,059 & $<0,1$ & jó \\
\hline INKREMENTÁLIS ILLESZKEDÉs & & & \\
TLI: Tucker-Lewis-index & 0,967 & $>0,9$ & jó \\
IFI (incremental fit index) & 0,972 & $>0,9$ & jó \\
CFI (comparative fit index) & 0,972 & $>0,9$ & jó \\
\hline PARSZINOMIÁLIS ILLESZKEDÉs & & & \\
PGFI (parsimony-adjusted goodness of fit index) & 0,741 & $>0,5$ & jó \\
PCFI (parsimony-adjusted comparative fit index) & 0,834 & $>0,5$ & jó \\
PNFI (parsimony-adjusted normed fit index) & 0,833 & $>0,5$ & jó \\
\hline
\end{tabular}


Fenti tesztek, validitás-, megbízhatóság- és illeszkedésvizsgálatok alapján a modellünk az elérhető konstrukciók közül a legjobb, jól interpretálható, és alkalmas további elemzésekre, következtetések levonására. A továbbiakban az exploratív faktoranalízis segítségével kialakított öt változóval dolgozunk, az így kialakított modell a konfirmatív fakoranalízis alapján érvényes és jól illeszkedő.

\section{Az Ajzen-modell vizsgálata strukturális egyenletekkel}

Fenti elemzések után kijelenthető, hogy a létrehozott faktorok minden tekintetben kifejezhetők a vizsgálatba bevont megfigyelt változók lineáris kombinációjaként, azaz a kifejezett faktorsúlyok alkalmasak arra, hogy azokból a vizsgált öt faktorváltozót kifejezzük. Ezek a változók Ajzen modelljének változói, így a faktormodellünk faktoraival felépíthetjük és tesztelhetjük az Ajzen-modellt. Ezt több lépésben, több különböző konstrukcióban végezzük strukturális egyenletek segítségével, kauzális modellekkel.

A munka során csak 2204 hallgató válaszait tudtuk elemezni az 5677 elemü adatbázisból. Ennek oka, hogy az aktuális magatartási kontroll és a cselekvés kérdései feltételes kérdések voltak, amelyeket csak azon hallgatóknak kellett megválaszolniuk, akik nem utasították el teljes mértékben a vállalkozás lehetőségét.

Az eredeti AJZen-MODell • Az eredeti Ajzen-modellből (Ajzen [2006a]) indulunk ki a hipotézisek teszteléséhez. Ebben a modellben hiányzik az aktuális viselkedés kontrollfaktora. Az okozati lánc első tagjai egyenrangúan és függetlenül az attitüdök, a szubjektív normák és az észlelt magatartás kontrolljai. E faktorok közé az eredeti Ajzen-modellnek megfelelően kovarianciákat illesztettünk (ez javítja is némileg a modell illeszkedését). Az első számú - közvetett - okozat a modellben a szándék, amely egyben okként is megjelenik a cselekvést illetôen. Így a magyarázott változó a modellben a cselekvés, amely közvetlenül a szándékkal, közvetetten - a szándékon keresztül - pedig az attitüdökkel, a szubjektív normákkal és az észlelt magatartási kontrollal függ össze.

Az iterációk után adódó modellben feltüntettük a regressziós $\beta$-kat is (2. ábra).

A modell szignifikáns interakciós hatásait mutatja a 7. táblázat. Látható, hogy mind a négy hatás szignifikáns, bár a szubjektív normák és a szándék között ellentétes irányú a kapcsolat. Mindemellett ez a kapcsolat és az észlelt magatartáskontroll-szándék közötti kapcsolat egyaránt gyenge. A becsült paraméterek standard hibái igen alacsonyak, és ebből adódóan a kritikus értékek (CR) meglehetősen magasak (mind a kívánatos 1,96-os érték felett van, jelezve, hogy minden út szignifikáns).

Az egyes okozati változóknál feltüntetett determinációs együtthatók jelzik, hogy a vizsgált okok milyen mértékben magyarázzák az adott okozatot (8. táblázat). A nem túl erős $\beta$-k alapján a determinációs együtthatók is viszonylag alacsonyak: a szándékot a vizsgált három okozati faktor 24 százalékban magyarázza $\left(R^{2}=0,24\right)$; illetve a cselekvést közvetlenül a szándék, valamint közvetve a másik három változó 33 százalékban magyarázza $\left(R^{2}=0,33\right)$. Ez a kumulatív hatás szignifikáns $(p=0,000)$. A fenti gyenge, illetve közepesen erős kapcsolatokkal együtt a modell illeszkedése igen jó. 
2. ábra

Ajzen-féle SEM modell standardizált regressziós súlyokkal és aktuális magatartási kontroll (АCT) nélkül, kovarianciák beiktatásával

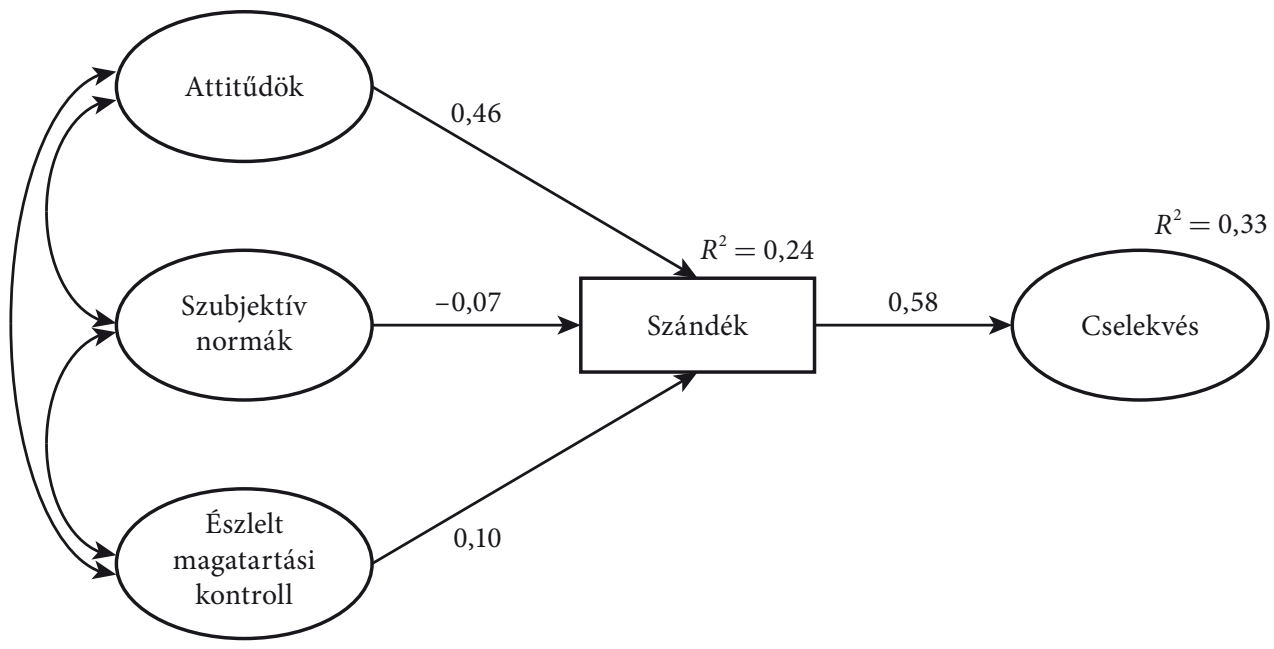

7. táblázat

A SEM modell standardizálatlan regressziós súlyai

\begin{tabular}{llcrrrr}
\hline & & & Becsült $\beta$ & SE & CR & $p$ \\
\hline Vállalkozási szándék & $\leftarrow$ & Attitüdök & 0,446 & 0,013 & 34,529 & $* * *$ \\
Vállalkozási szándék & $\leftarrow$ & Észlelt magatartási kontroll & 0,132 & 0,021 & 6,382 & $* * *$ \\
Vállalkozási szándék & $\leftarrow$ & Szubjektív normák & $-0,117$ & 0,022 & $-5,233$ & $* * *$ \\
Cselekvés & $\leftarrow$ & Vállalkozási szándék & 0,432 & 0,008 & 51,479 & $* * *$ \\
\hline
\end{tabular}

${ }^{* * *} p<0,001$.

Fentiek alapján a bemutatott Ajzen-modell jól illeszkedik a GUESSS kutatás adataira. Bár az észlelt magatartási kontroll és a vállalkozási szándék, valamint a szubjektív normák és a vállalkozási szándék közötti kapcsolat gyenge (ráadásul ez utóbbi negatív is), de mindegyik szignifikáns ( $p<0,001)$.

Ha kizárólag a modell erősebb kapcsolatait nézzük, akkor egy jól definiált okozati láncot emelhetünk ki az eredeti modellből. Ez a következő: attitüdök $\Rightarrow$ szándék $\Rightarrow$ cselekvés.

AJZEN-MOdell KiterJeszTetT OKOZATi LÁNCCAL • A hipotézisek teszteléséhez (3.A és 3.B HIPOTÉZIS) és a modell illeszkedésének javításához beépítettük az oksági kapcsolatokat a szubjektív normák és az attitüdök, illetve az észlelt magatartási kontroll közé. Emiatt ki kell venni a modellből a kovarianciákat, hiszen az összefüggő változók nem kovariálhatók. Ebben az esetben szignifikáns kapcsolat adódott a szubjektív normák és az attitüdök, valamint az észlelt magatartási kontroll között is. Ám a köztes okozati változók (attitűdök és észlelt magatartási kontroll) csak igen kis mértékben magyarázhatók 
8. táblázat

A modell illeszkedésének mérőszámai

\begin{tabular}{lccc}
\hline Statisztika & Érték & Küszöb & Eredmény \\
\hline ABSzolút ILLESZKEDÉs & & & \\
GFI (goodness of fit index) & 0,86 & $>0,8$ & jó \\
RMSR (root mean square residual) & 0,115 & $<0,08$ & mérsékelt \\
RMSEA (root mean square error of approximation) & 0,078 & $<0,1$ & jó \\
\hline INKREMENTÁLIS ILLESZKEDÉs & & & \\
TLI: Tucker-Lewis-index & 0,956 & $>0,9$ & jó \\
IFI (incremental fit index) & 0,961 & $>0,9$ & jó \\
CFI (comparative fit index) & 0,961 & $>0,9$ & jó \\
\hline PARSZINOMIÁLIS ILLESZKEDÉs & & & jó \\
PGFI (parsimony-adjusted goodness of fit index) & 0,705 & $>0,5$ & jó \\
PCFI (parsimony-adjusted comparative fit index) & 0,857 & $>0,5$ & jó \\
PNFI (parsimony-adjusted normed fit index) & 0,856 & $>0,5$ & \\
\hline
\end{tabular}

a szubjektív normákkal, amelyeket az alacsony determinációs együtthatók jeleznek (rendre 6 és 10 százalék). A szándékot már jobban magyarázza az előző két mediatív változó: ennek determinációs együtthatója 23 százalék. A teljes modell magyarázó ereje pedig 33 százalék, azaz a cselekvés összetevőinek harmada származtatható az Ajzenmodellből (3. ábra). Ez a kumulatív hatás szignifikáns $(p=0,000)$.

Ebben a modellben is minden kapcsolat szignifikáns, de már több a közepesen erős utak száma. Két úttól eltekintve (a szándékot befolyásoló észlelt magatartási kontroll, illetve szubjektív normák) minden regressziós $\beta$ viszonylag magas (9. táblázat). A becsült paraméterek standard hibái alacsonyak, és ebböl adódóan a kritikus értékek (CR) is meglehetősen magasak (mind a kívánatos 1,96-os érték felett van - abszolút értékben -, jelezve, hogy minden út szignifikáns). A kumulatív hatás szignifikáns $(p=0,000)$.

\section{9. táblázat}

A SEM-modell standardizálatlan regressziós súlyai

\begin{tabular}{lccccccc}
\hline & & Becsült $\beta$ & SE & CR & $p$ \\
\hline Attitüdök & $\leftarrow$ & Szubjektív normák & 0,416 & 0,026 & 16,049 & $* * *$ \\
Észlelt magatartási & $\leftarrow$ & Szubjektív normák & 0,413 & 0,023 & 18,253 & $* * *$ \\
kontroll & & & & & & \\
Vállalkozási szándék & $\leftarrow$ & Attitüdök & 0,453 & 0,012 & 37,153 & $* * *$ \\
Vállalkozási szándék & $\leftarrow$ & Észlelt magatartási kontroll & 0,128 & 0,019 & 6,773 & $* * *$ \\
Vállalkozási szándék & $\leftarrow$ & Szubjektív normák & $-0,121$ & 0,023 & $-5,274$ & $* * *$ \\
Cselekvés & $\leftarrow$ & Vállalkozási szándék & 0,432 & 0,008 & 51,045 & $* * *$ \\
\hline
\end{tabular}

${ }^{* * *} p<0,001$. 
3. ábra

Ajzen-féle SEM modell standardizált regressziós súlyokkal és aktuális magatartási kontroll (АCT) nélkül

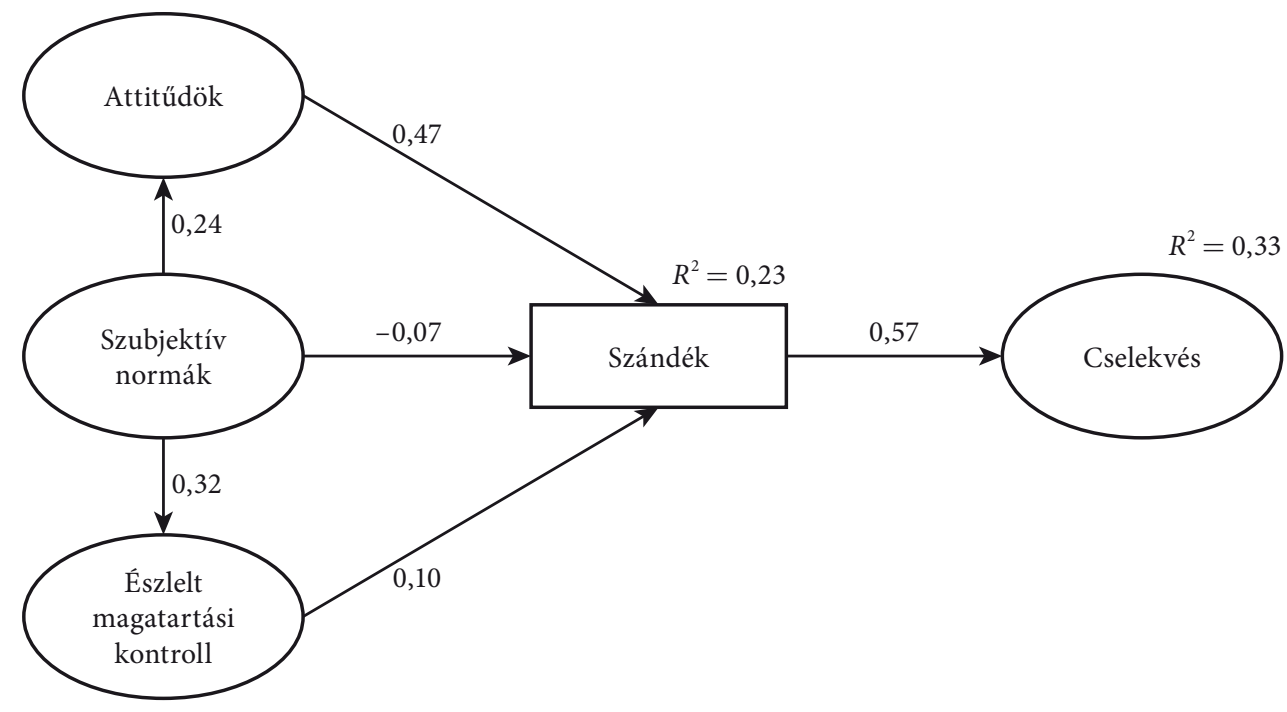

Csakúgy, mint a kovarianciás modell esetében, itt is jó a modell illeszkedése, tehát jól interpretálható és megbízható a modell (10. táblázat).

10. táblázat

A modell illeszkedésének mérőszámai

\begin{tabular}{lccc}
\hline Statisztika & Érték & Küszöb & Eredmény \\
\hline ABSzolút ILLESZKEDÉs & & & \\
GFI (goodness of fit index) & 0,855 & $>0,8$ & jó \\
RMSR (root mean square residual) & 0,135 & $<0,08$ & mérsékelt \\
RMSEA (root mean square error of approximation) & 0,079 & $<0,1$ & jó \\
\hline INKREMENTÁLIS ILLESZKEDÉs & & & \\
TLI: Tucker-Lewis-index & 0,955 & $>0,9$ & jó \\
IFI (incremental fit index) & 0,959 & $>0,9$ & jó \\
CFI (comparative fit index) & 0,959 & $>0,9$ & jó \\
\hline PARSZINOMIÁLIS ILLESZKEDÉs & & & jó \\
PGFI (parsimony-adjusted goodness of fit index) & 0,704 & $>0,5$ & jó \\
PCFI (parsimony-adjusted comparative fit index) & 0,859 & $>0,5$ & jó \\
PNFI (parsimony-adjusted normed fit index) & 0,858 & $>0,5$ &
\end{tabular}


Hasonlóan az előző modellhez, itt is ki tudjuk ragadni azt a viszonylag erős okozati láncot, amely végigfut a modellen, ám ez kiegészül alapokozatként a szubjektív normákkal: szubjektív normák $\Rightarrow$ attitüdök $\Rightarrow$ szándék $\Rightarrow$ cselekvés. Itt meg kell jegyezni, hogy bár a szubjektív normák és az észlelt magatartási kontroll között is viszonylag erős a kapcsolat $(0,32)$, ez utóbbi faktor és a szándék között alacsony $(0,10)$, ezért nem ezt az utat vontuk be az okozati láncba.

AKTUÁlis MAgATARTÁSI KONTROLl BeÉPÍTÉSE A MODELlbe • Az aktuális magatartási kontrollfaktor beépítésével a modell tovább fejleszthető. Az előző változathoz hasonló módon - mivel az oksági viszony itt is fennáll a szubjektív normák és az attitüdök, illetve az észlelt magatartási kontroll között - kovarianciák nem illeszthetők e három változó közé, azonban a modell illeszkedésének javítása érdekében a szubjektív normák és az aktuális magatartási kontroll közé - mivel közöttük nem áll fenn közvetlen oksági viszony - már igen. A 4. ábrán jól láthatóan az aktuális magatartási kontroll is részt vesz a modell magyarázatában, bár viszonylag kis erősséggel. Az észlelt magatartási kontrollal ellentétes irányú a kapcsolata (bár gyenge, de szignifikáns), amit a Likert-skála iránya okoz. Az egyes közbenső okozatok magyarázata esetenként itt is relatíve alacsony marad (attitüdök 6 százalék, észlelt magatartási kontroll 16 százalék, szándék 23 százalék, és a teljes modell magyarázó ereje 41 százalék). A teljes kumulatív hatás szignifikáns ( $p=0,000)$.

\section{4. ábra}

Kibővített Ajzen-féle SEM modell standardizált regressziós súlyokkal

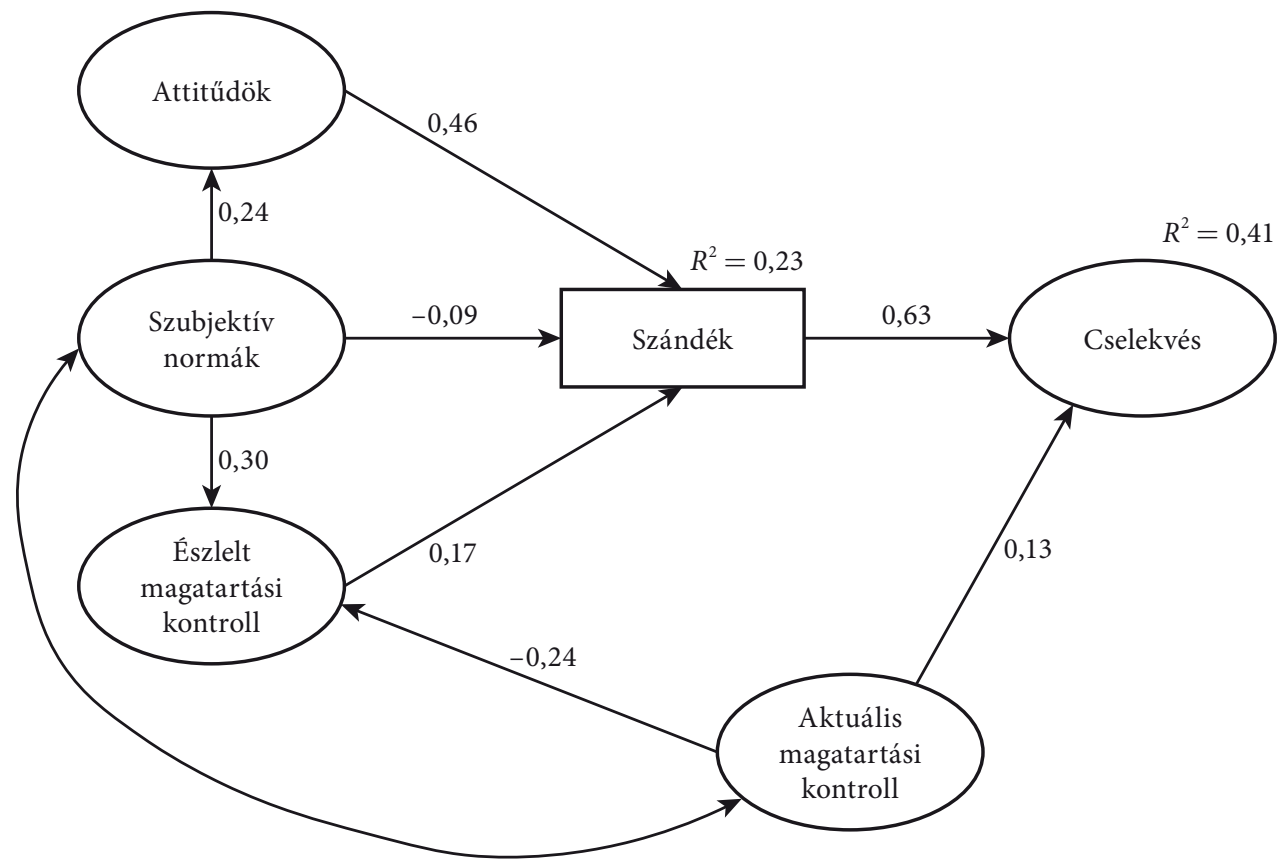

A modell összes kapcsolata szignifikáns, és itt már megjelennek erősebb kapcsolatok is. Három olyan utat tartalmaz a modell, ahol a kapcsolatok szorossága meglehetősen 
alacsony. A standard hibák azonban mindenütt kellően alacsonyak, és ennek megfelelően a kritikus értékek magasak. A modellben minden út szignifikáns (11. táblázat).

11. táblázat

A SEM modell standardizálatlan regressziós súlyai

\begin{tabular}{|c|c|c|c|c|c|c|}
\hline & & & Becsült $\beta$ & SE & $\mathrm{CR}$ & $p$ \\
\hline Attitüdök & $\leftarrow$ & Szubjektív normák & 0,418 & 0,026 & 16,094 & $* * *$ \\
\hline $\begin{array}{l}\text { Észlelt magatartási } \\
\text { kontroll }\end{array}$ & $\leftarrow$ & Szubjektív normák & 0,365 & 0,021 & 17,371 & $* * *$ \\
\hline $\begin{array}{l}\text { Észlelt magatartási } \\
\text { kontroll }\end{array}$ & $\leftarrow$ & Aktuális magatartási kontroll & $-0,165$ & 0,011 & $-15,273$ & $* * *$ \\
\hline Vállalkozási szándék & $\leftarrow$ & Attitüdök & 0,434 & 0,012 & 35,903 & $* * *$ \\
\hline Vállalkozási szándék & $\leftarrow$ & Észlelt magatartási kontroll & 0,230 & 0,020 & 11,229 & $* * *$ \\
\hline Vállalkozási szándék & $\leftarrow$ & Szubjektív normák & $-0,150$ & 0,023 & $-6,52$ & $* * *$ \\
\hline Cselekvés & $\leftarrow$ & Aktuális magatartási kontroll & 0,100 & 0,008 & 12,424 & $* * *$ \\
\hline Cselekvés & $\leftarrow$ & Vállalkozási szándék & 0,512 & 0,009 & 59,955 & $* * *$ \\
\hline
\end{tabular}

${ }^{* * *} p<0,001$.

A modell illeszkedése ebben az esetben is igen jó, ahogyan a 12. táblázatbeli tesztek eredményei is mutatják. Így a modell jól interpretálható.

\section{2. táblázat}

A modell illeszkedésének mérőszámai

\begin{tabular}{lccc}
\hline Statisztika & Érték & Küszöb & Eredmény \\
\hline ABszOLÚT ILLESZKEDÉs & & & \\
GFI (goodness of fit index) & 0,804 & $>0,8$ & jó \\
RMSR (root mean square residual) & 0,108 & $<0,08$ & mérsékelt \\
RMSEA (root mean square error of approximation) & 0,093 & $<0,1$ & jó \\
\hline INKREMENTÁLIS ILLESZKEDÉs & & & \\
TLI: Tucker-Lewis-index & 0,914 & $>0,9$ & jó \\
IFI (incremental fit index) & 0,921 & $>0,9$ & jó \\
CFI (comparative fit index) & 0,921 & $>0,9$ & jó \\
\hline PARSZINOMIÁLIS ILLESZKEDÉs & & & jó \\
PGFI (parsimony-adjusted goodness of fit index) & 0,672 & $>0,5$ & jó \\
PCFI (parsimony-adjusted comparative fit index) & 0,849 & $>0,5$ & jó \\
PNFI (parsimony-adjusted normed fit index) & 0,848 & $>0,5$ & \\
\hline
\end{tabular}




\section{Következtetések}

Mivel a bemutatott modellek minden tekintetben megfelelnek a módszertan által támasztott követelményeknek, így alkalmasak arra, hogy következtetéseket vonjunk le. Ehhez tekintsük a három - részben különböző - regressziós modell paramétereinek standardizált ${ }^{3}$ becsléseit (a becslés egyéb mutatóit itt már nem tüntetjük fel, minden érték szignifikáns).

A 13. táblázatból látható, hogy az egyes modellek meglehetősen hasonló paramétereket becsültek a különböző modellekben, ez tovább erősíti az interpretáció megbízhatóságát. A legnagyobb magyarázó ereje a kibővített modellnek van (41 százalék, ám ez nem meglepő, mivel itt van a legtöbb változó és a legtöbb út).

\section{3. táblázat}

Az egyes SEM modellek standardizált becsült paraméterei

\begin{tabular}{|c|c|c|c|c|c|c|}
\hline & & \multicolumn{3}{|c|}{ Becsült $\beta$} & \multirow{2}{*}{ Hipotézis } & \multirow{2}{*}{$\begin{array}{c}\text { Konklúzió } \\
(p)\end{array}$} \\
\hline & & $\begin{array}{l}\text { eredeti } \\
\text { Ajzen- } \\
\text { modell } \\
\text { kovarian- } \\
\text { ciákkal }\end{array}$ & $\begin{array}{l}\text { eredeti } \\
\text { Ajzen- } \\
\text { modell }\end{array}$ & $\begin{array}{c}\text { kibővített } \\
\text { Ajzen- } \\
\text { modell }\end{array}$ & & \\
\hline Attitüdök & $\leftarrow$ Szubjektív normák & - & 0,24 & 0,24 & 3.A & $P^{* * *}$ \\
\hline $\begin{array}{l}\text { Észlelt magatartási } \\
\text { kontroll }\end{array}$ & $\leftarrow$ Szubjektív normák & - & 0,32 & 0,30 & 3. $\mathrm{B}$ & $P^{* * *}$ \\
\hline $\begin{array}{l}\text { Észlelt magatartási } \\
\text { kontroll }\end{array}$ & $\begin{array}{c}\leftarrow \text { Aktuális magatartási } \\
\text { kontroll }\end{array}$ & - & - & $-0,24$ & 5.B & $P^{* * *}$ \\
\hline $\begin{array}{l}\text { Vállalkozási } \\
\text { szándék }\end{array}$ & $\leftarrow \quad$ Attitüdök & 0,46 & 0,47 & 0,46 & 2 & $P^{* * *}$ \\
\hline $\begin{array}{l}\text { Vállalkozási } \\
\text { szándék }\end{array}$ & 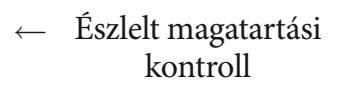 & 0,10 & 0,10 & 0,17 & 4 & $P^{* * *}$ \\
\hline $\begin{array}{l}\text { Vállalkozási } \\
\text { szándék }\end{array}$ & $\leftarrow$ Szubjektív normák & $-0,07$ & $-0,07$ & $-0,09$ & & \\
\hline Cselekvés & $\begin{array}{c}\leftarrow \text { Aktuális magatartási } \\
\text { kontroll }\end{array}$ & $\mathrm{n} / \mathrm{a}$ & $\mathrm{n} / \mathrm{a}$ & 0,13 & 5.A & $P^{* * *}$ \\
\hline Cselekvés & $\leftarrow$ Vállalkozási szándék & 0,58 & 0,57 & 0,63 & & \\
\hline$R^{2}$ & & 0,33 & 0,33 & 0,41 & & \\
\hline
\end{tabular}

Megjegyzés: a modell az adott utat nem tartalmazza (-), a hipotézis igazolt $(\mathrm{P}),{ }^{* * *} p<0,001$.

\footnotetext{
${ }^{3}$ Mivel a következtetéseinkben szeretnénk kiküszöbölni annak hatását, hogy az egyes változóknak eltérő a szóródása, illetve a „szándék” változó nem faktor, hanem megfigyelt változó, így itt is a standardizált paramétereket használjuk.
} 
A közepes és erősebb kapcsolatokat kiemelve az elemzésekből, elkészítettük a cselekvést befolyásoló tényezők hatásainak elemzését. Ehhez a legerősebb magyarázó erővel rendelkező (kibővített) modell paramétereit használtuk, a másik két modellt pedig e kapcsolatok kontrolljaként verifikálásra (ez minden esetben meg is tehetö, hiszen a becsült paraméterek értéke nem különbözik jelentősen).

Megállapíthatjuk, hogy a szubjektív normák meghatározzák az attitüdöket, és befolyásolják az észlelt magatartási kontrollt is. Tehát a környezet vélekedései fontos alakítói a vállalkozói attitüdöknek, valamint annak is, hogy az egyén menynyire érzi úgy, hogy birtokában van annak a tudásnak, amely őt sikeres vállalkozóvá teheti, mennyire érzi úgy, hogy képes irányítani életének eseményeit. A normák vállalkozási szándékra gyakorolt közvetlen hatása ugyanakkor meglehetősen kicsi, előjele negatív. (Itt meg kell jegyeznünk, hogy a mutató rendkívül alacsony értéke miatt az előjelének alakulása bizonytalan, így értelmezését nem kíséreljük meg.) Ezek a kapcsolatok hasonló erősséggel megjelennek az eredeti Ajzen-modell alapján létrehozott SEM modellben is.

$\mathrm{Az}$ attitüdök közvetlen hatást gyakorolnak a vállalkozási szándékra. Ez a kapcsolat mindhárom SEM modellben megjelenik, hasonló erősséggel. Minél kedvezőbben viszonyul a vállalkozói tevékenységhez az egyén, amiben tehát az egyén környezetének (a családnak, a barátoknak, a felsőoktatási környezetnek) jelentős szerepe van, annál inkább el tudja képzelni magát a vállalkozói szerepben. Az attitüdök és a normák közötti kapcsolat azt sejteti, hogy a vállalkozók, a vállalkozás társadalmi megbecsültségének növelésével, azaz a társadalom részéről érkező pozitív megerősítéssel formálható a hallgatói attitüd, és befolyásolható a vállalkozásindítási szándék.

A kialakult szándék mindhárom modellváltozatban erőteljesen meghatározza a cselekvést, ami pedig megerösíti azt a feltevést, hogy van helye a vállalkozásindítási szándék és legfontosabb befolyásolói vizsgálatának. A modellből azt láthatjuk, hogy a szubjektív normák az attitüdökön keresztül erősítik a vállalkozási szándék kialakulását, ami pedig a cselekvéshez vezet. Így az okozati lánc a következö:

szubjektív normák $\Rightarrow$ attitüdök $\Rightarrow$ szándék $\Rightarrow$ cselekvés

Az aktuális magatartási kontroll pozitívan befolyásolja az észlelt magatartási kontrollt. A negatív értéket az alkalmazott Likert-skála iránya okozza (a kérdés így szólt: ...az alábbiak mennyire akadályozzák üzleti vállalkozásod alapitását?), azaz minél kisebbek az akadályok, az egyén minél inkább rendelkezik a szükséges erőforrásokkal, annál magabiztosabbnak érzi magát.

A további utak bár szignifikánsak, gyengék a modellben, ezért ezeket az 5. ábrán csak szaggatott vonallal jelöljük.

Az eredmények értelmében egyértelmủen elfogadjuk az 1., 2., 3.A, 3.B és 5.B HIPOTÉZIST ( $p=0,000$ ), és a kapcsolat gyengesége miatt fenntartásokkal fogadjuk el a 4 . és 5.A HIPOTÉZIST $(p=0,000)$. 
5. ábra

A vállalkozásindítási szándék közvetlen és közvetett befolyásoló tényezői

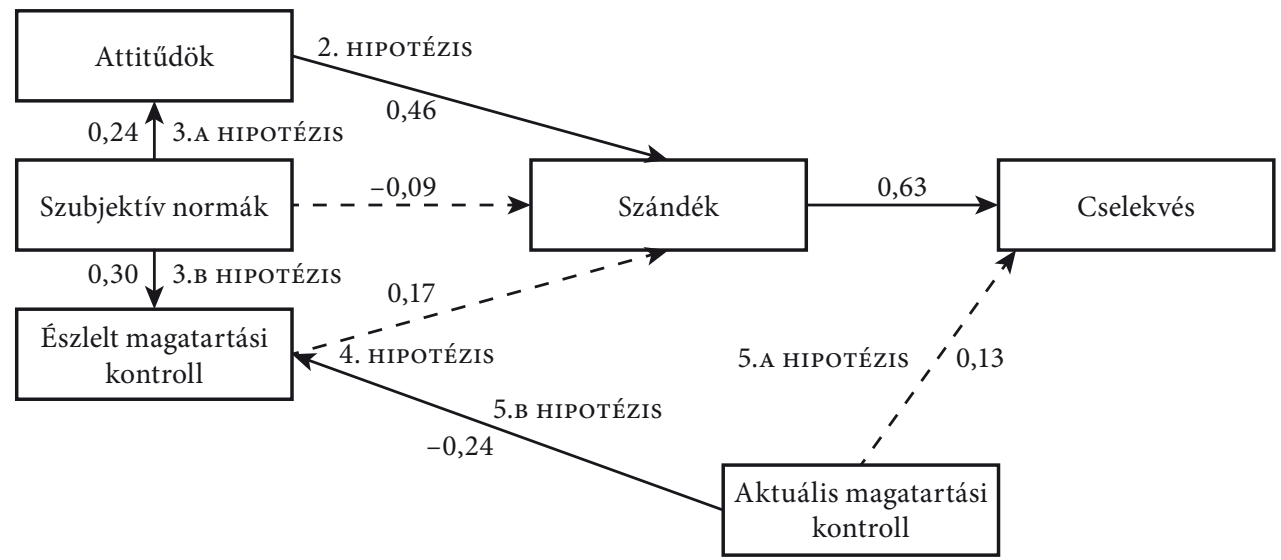

\section{Összegzés}

A vállalkozói hajlandóság alakulásának megértése kulcsfontosságú a vállalkozásösztönzés területén. Ajzen tervezettmagatartás-elméletének felhasználásával jelen cikkben arra törekedtünk, hogy megértsük a vállalkozásindításra irányuló bonyolult döntés természetét. A GUESSS-adatbázison végzett tesztek alapján a következő megállapításokat tehetjük.

- A szubjektív normák meghatározzák az attitűdöket, és befolyásolják az észlelt magatartási kontrollt is.

- Az attitüdök meghatározzák a szándékot.

- A szándék erőteljesen meghatározza a cselekvést.

- Az aktuális magatartási kontroll az észlelt magatartási kontroll fontos alakítója.

Az attitűdök és a normák közötti kapcsolat azt sejteti, hogy a vállalkozók, a vállalkozás társadalmi megbecsültségének növelésével, azaz a társadalom részéről nyújtott pozitív megerősítéssel formálható a hallgatói attitűd, és befolyásolható a vállalkozásindítási szándék.

A vállalkozásindításhoz, vállalkozási folyamathoz szükséges erőforrások elérhetővé tétele (aktuális kontroll) nagyban hozzájárul az észlelt magatartási kontroll alakításához, ugyanakkor ez utóbbi tényező vállalkozási szándékra gyakorolt hatása csekély. Ez arra utalhat, hogy a döntést nem elsősorban az befolyásolja, hogy mennyi erőforrás áll rendelkezésre a vállalkozáshoz (például a vállalkozásindításhoz szükséges pénz, eszközök stb. elérhetők-e az egyén számára).

Míg a forrásbiztosítás viszonylag gyorsan megoldható, könnyen alakítható, addig az attitüdök formálása igen időigényes lehet, következetes és hosszú távú beavatkozást követel meg. Ami azt sejteti, hogy a vállalkozási szándék érdemi növelése bár rendkívül fontos a vállalkozói aktivitás növelése érdekében, de hosszú időt igénybe vevő, lassú folyamat. 
Noha a szubjektív normák és az attitűdök formálása lényeges kérdésnek tűnik a hallgatói vállalkozói szándék növelése és a vállalkozásindítás fokozása szempontjából, ezek a tényezők érdemben csak átgondolt stratégiával, hosszú távon alakíthatók. Az oktatás ebben kiemelt szerepet játszhat, a közoktatásban és a felsőoktatásban egyaránt.

Fontosnak tartjuk, hogy a felsőoktatás minden képzési területén megjelenjen a vállalkozási ismeretek oktatása legalább választható kurzus vagy kurzusok formájában. A következö lépés a hallgatói vállalkozási ötletek, vállalkozások indításának támogatása az intézményi erőforrások bővítésével. Ideértjük az inkubációt, a versenyek hirdetését, a megvalósítható ötletek pénzügyi támogatását. A felsőoktatási intézmények jelenlegi jó gyakorlatai között megtaláljuk külföldön már bizonyított megoldások adaptálását, beillesztve a létező képzési struktúrába, ilyen például a Team Academy (Debreceni Egyetem, Budapesti Gazdasági Egyetem). Van olyan intézmény, amelyben komoly hagyománya van a hallgatói vállalkozási ötletek támogatásának üzleti kurzusok szervezésével, mentorálással és kockázati tőke biztosításával. Erre példa a Spin-off Klub (Budapesti Corvinus Egyetem), amely 2011 óta müködik.

Tudjuk, hogy a vállalkozók alacsony társadalmi elfogadottsága negatívan hat a vállalkozói hajlandóság alakulására. Nem segítenek ezen a média és az internetes közösségi platformok sem, amelyek bővelkednek a vállalkozókat negatívan leíró hírek közlésében (Szerb-Kocsis-Kisantal [2008]). Itt fontos kitörési pontnak érezzük a fiatal vállalkozók sikertörténeteit. Számos sikeres, nemzetközileg is jelentős startup, illetve ezt a fejlödési szakaszt elhagyó vállalkozás müködik, amelyek közül jó néhány szélesebb publicitást is kap, és ez hozzájárulhat ahhoz is, hogy negatívumok helyett a vállalkozási folyamatnak az értékteremtő volta kerüljön előtérbe.

A felsőoktatásban a hallgatókat megcélzó szolgáltatások megteremtése mellett kiemelt fontosságú az oktatók oktatási-kutatási tevékenysége, valamint a felsőoktatási és akadémiai intézményekből kiváló (kipörgetett - spin-off) vállalkozások működése, amelyek ezen intézményekben létrehozott ötletek, találmányok üzleti hasznosítására hivatottak. A vállalkozóként is sikeres egyetemi oktatók példája valószínüleg tucatnyi üzleti kurzus szemléletalakító hatásával érne fel.

\section{Hivatkozások}

Ajzen, I. [1991]: The Theory of Planned Behavior Organizational. Behavior and Human Decision Processes, Vol. 50. No. 2. 179-211. o. https://doi.org/10.1016/0749-5978(91)90020-T. AJZen, I. [2006a]: Constructing a Theory of Planned Behavior Questionnaire. Brief Description of the Theory of Planned Behavior. http://people.umass.edu/aizen/pdf/tpb. measurement.pdf.

AJzen, I. [2006b]: Behavioral Interventions Based on the Theory of Planned Behavior. Technical Report, január, https://people.umass.edu/aizen/pdf/tpb.intervention.pdf.

Autio, E. [2005]: Report on High-Expectation Entrepreneurship. Global Entrepreneurship Monitor, London Business School - Babson College, http://new.gemconsortium.org/assets/ uploads/1313506401GEM_2005_High_Growth_Report.pdf. 
Autio, E.-Wennberg, K. [2010]: You think, therefore, I become: Social attitudes and the transition to entrepreneurship. Paper presented at DRUID Summer Conference 2010, Imperial College London Business School, London, június 16-18.

Autio, E.-Keeley, R. H.-Klosfsten, M.-PArker, G. C.- AY, M. [2001]: Entrepreneurial Intent among Students in Scandinavia and in the USA. Enterprise and Innovation Management Studies, Vol. 2. No. 2. 145-160. o. http://dx.doi.org/10.1080/14632440110094632.

Bandura, A. [1977]: Social Learning Theory. Prentice-Hall, Englewood Cliffs, New Jersey.

Bandura, A. [1989]: Social cognitive theory. Megjelent: Vasta, R. (szerk.): Annals of child development. Vol. 6. Six theories of child development. JAI Press, Greenwich, CT, 1-60. o.

Borsi BALÁzs-DőRY Tibor [2015]: A vállalkozóképzés nemzetközi trendjei és a vállalkozói készségek egyetemi fejlesztése. Közgazdasági Szemle, 62. évf. 7-8. sz. 835-852. o.

Carmines, E. G.-Zeller, R. A. [1979]: Reliability and Validity Assessment. Sage, Beverly Hills, CA.

Carree, M. A.-Thurik, A. R. [2010]: The Impact of entrepreneurship on Economic Growth. Megjelent: Acs, Z.-Audretsch, D. (szerk.): International Handbook of Entrepreneurship Research. 2. kiadás. Springer, New York, 557-594. o.

Cronbach, L. J. [1951]: Coefficient alpha and the internal structure of tests. Psychometrika, Vol. 16. No. 3. 297-334. o. https://doi.org/10.1007/bf02310555.

EC [2008]: Entrepreneurship in Higher Education, Especially within Non-business Studies. Final Report of the Expert Group European Commission, Enterprise and Industry Directorate-General Promotion of SMEs competitiveness Entrepreneurship. European Commission, Brüsszel, http://ec.europa.eu/DocsRoom/documents/2214/attachments/1/ translations/en/renditions/native.

EC [2013]: Entrepreneurship 2020 Action Plan. European Commission, Brüsszel, http://ec. europa.eu/growth/smes/promoting-entrepreneurship/action-plan.

EC [2015]: Erasmus for Young Entrepeneurs. Programme Guide. European Commission, Brüsszel, http://www.erasmus-entrepreneurs.eu/upload/Programme\%20Guide\%20 EN\%20May\%202015.pdf.

Engle, R. L.-Dimitriadi, N.-Gavidia, J. V.-Schlaegel, Ch.-Delanoe, S.-Alvarado, I.He, X.-Buame, S.-Wolff, B. [2010]: Entrepreneurial Intent: A Twelve-country Evaluation of Ajzen's Model of Planned Behavior. International Journal of Entrepreneurial Behavior and Research, Vol. 16. No. 1. 35-57. o. https://doi.org/10.1108/13552551011020063.

Eurofound [2015]: Youth entrepreneurship in Europe: Values, attitudes, policies. Publications Office of the European Union, Luxembourg, https://www.eurofound.europa.eu/sites/ default/files/ef_publication/field_ef_document/ef1507en.pdf.

ForNELL, C.-LARCKER, D. F. [1981]: Evaluating structural equation models with unobservable variables and measurement error. Journal of Marketing Research, Vol. 18. No. 1. 39-50. o. https://doi.org/10.2307/3151312.

Hair, J.-Black, W.-Babin, B.-Anderson, R. [2010]: Multivariate Data Analysis. 7. kiadás. Prentice-Hall, Upper Saddle River, NJ.

Hope, K. (szerk.) [2016]: Annual Report on European SMEs 2015/2016. SME Recovery Continues. European Commission, https://doi.org/10.2873/76227.

IMREH-Tóth MóniKa [2015]: Az egyetemi vállalkozásoktatás lehetséges szerepe a vállalkozóvá válás elősegítésében. JATEPress, Szeged, 150 o.

Jöreskog, K. G. [1969]: A General Approach to Confirmatory Factor Analysis. Psychometrika, Vol. 34. No. 2. 183-202. o. https://doi.org/10.1007/bf02289343. 
KAISER, J. F. [1974]: Using the $\mathrm{I}_{0}$ - sinh Window Function. IEEE Transactions on Circuits and Systems. Fundamental Theory and Applications, April, 123-126. o.

Kautonen, T.-van Gelderen, M.-Fink, M. [2015]: Robustness of the Theory of Planned Behavior in Predicting Entrepreneurial Intentions and Actions. Entrepreneurship Theory and Practice, Vol. 39. No. 3. 655-674. o. https://doi.org/10.1111/etap.12056.

Kolvereid, L. [1996]: Prediction of Employment Status Choice Intentions: Entrepreneurs. Entrepreneurship: Theory and Practice, Vol. 21. No. 1. 47-57. o. http://journals.sagepub. com/doi/pdf/10.1177/104225879602100104.

Krueger, N.-Reilly, M. D.-Carsrud, A. L. [2000]: Competing Models of Entrepreneurial Intentions. Journal of Business Venturing, Vol. 15. No. 5-6. 411-432. o. https://doi. org/10.1016/s0883-9026(98)00033-0.

KSH [2016]: A kis- és középvállalkozások jellemzői - adat-előállítás új módszertannal. Központi Statisztikai Hivatal, Budapest, november, http://www.ksh.hu/docs/hun/xftp/ idoszaki/pdf/kkv15.pdf.

LiÑÁn, F.-Chen, Y.-W. [2009]: Development and Cross-Cultural Application of a Specific Instrument to Measure Entrepreneurial Intentions. Entrepreneurship: Theory and Practice, Vol. 33. No. 3. 593-617. o. https://doi.org/10.1111/j.1540-6520.2009.00318.x.

LüthJe, C.-Franke, N. [2002]: Fostering Entrepreneurship through University Education and Training: Lessons from Massachusetts Institute of Technology. European Academy of Management, 2nd Annual Conference on Innovative Research in Management. Stockholm, május 9-11. http://citeseerx.ist.psu.edu/viewdoc/download?doi=10.1.1.203. 2530\&rep=rep1\&type $=$ pdf.

Meager, N.-Bates, P.-Cowling, M. [2003]: An evaluation of business start-up support for young people. National Institute Economic Review, Vol. 186. No. 1. 59-72. o. https://doi. org/10.1177/00279501031861007.

Mulaik, S. A.-James, L. R.-Van Alstine, J.-Bennett, N.-Lind, S.-Stilwell, C. D. [1989]: Evaluation of goodness-of-fit indices for structural equation models. Psychological Bulletin, Vol. 105. No. 3. 430-445. o. https://doi.org/10.1037//0033-2909.105.3.430.

Nishimura, J. S.-Tristán, O. M. [2011]: Using the Theory of Planned Behavior to Predict Nascent Entrepreneurship. Academia, Revista Latinoamericana de Administración, 46. 55-71. o. https://www.cladea.org/es/revista-academia.

Ozaralli, N.-Rivenburgh, N. K. [2016]: Entrepreneurial Intention: Antecedents to Entrepreneurial Behavior in the U.S.A. and Turkey. Journal of Global Entrepreneurship Research, Vol. 6. No. 3. https://doi.org/10.1186/s40497-016-0047-x.

Plant, R.-Ren, J. [2010]: A Comparative Study of Motivation and Entrepreneurial Intentionality: Chinese and American Perspectives. Journal of Developmental Entrepreneurship, Vol. 15. No. 2. 187-204. o. https://doi.org/10.1142/s1084946710001506.

Richert, J.-Schiller, R. [1994]: Hochschulabsolventen als Existenzgründer. Report of the „Deutsche Ausgleichsbank” for the Federal Ministry of Education and Science in Germany, Bonn.

S. Gubik Andrea [2013]: A magyar hallgatók vállalkozásindító szándékát befolyásoló tényezők modellje. Ajzen tervezett magatartás elméletének kiterjesztése. Vezetéstudomány, 44. évf. 7-8. o. 5-17. o.

S. GubiK ANDREA [2016]: Magyar egyetemi hallgatók karrierterveinek alakulása és kihatásuk a jövőbeli vállalkozói hajlandóságra. Megjelent: Tóth Attiláné-S. Gubik Andrea (szerk.): Magyarország 2025-ben és kitekintés 2050-re. Tanulmánykötet Nováky Erzsébet 70. születésnapjára. Arisztotelész Kiadó, 91-102. o. 
Schreiber, J. B.-Stage, F. K.-King, J.-Nora, A.-BArlow, E. A. [2006]: Modeling and Confirmatory Factor Analysis Results: A Review. The Journal of Educational Research, Vol. 99. No. 6. 323-338. o. https://doi.org/10.3200/joer.99.6.323-338.

Schrör, H. [2006]: The profile of the successful entrepreneur Results of the survey "Factors of Business Success". Statistics in Focus, 29/2006, Eurostat, http://ec.europa.eu/eurostat/documents/3433488/5443129/KS-NP-06-029-EN.PDF/22202ac8-b984-4b87-9f72$7 \mathrm{e} 774 \mathrm{e} 80 \mathrm{alac}$.

Shane, S.-Kolvereid, L.-Westhead, P. [1991]: An Exploratory Examination of the Reasons Leading to New Firm Formation Across Country and Gender. Journal of Business Venturing, Vol. 6. No. 6. 431-446. o. https://doi.org/10.1016/0883-9026(91)90029-d.

Shapero, A.-Sokol, L. [1982]: The social dimensions of entrepreneurship. Megjelent: Kent, C. A.-Sexton, D. L.-Vesper, K. H. (szerk.): Encyclopedia of entrepreneurship. Prentice-Hall, Englewood Cliffs, New Jersey, 72-90. o.

Snedecor, G. W.-Cochran, W. G. [1989]: Statistical Methods. Iowa State University Press, Ames.

Szerb LÁszló-Kocsis-Kisantal Orsolya [2008]: Vállalkozói kultúra Magyarországon két napilap tükrében. Közgazdasági Szemle, 55. évf. 3. sz. 243-261. o.

Szerb LÁszló-Lukovszki Lívia [2013]: Magyar egyetemi hallgatók vállalkozási attitűdjei és az attitüdöket befolyásoló tényezők elemzése a GUESSS-felmérés adatai alapján. Kik is akarnak ténylegesen vállalkozni? Vezetéstudomány, 44. évf. 7-8. sz. 30-40. o.

SzERB László-MÁrkus Gábor [2007]: A felsőoktatási környezet hatása a vállalkozói életpálya választására. Nemzetközi összehasonlító elemzés, 2006. Közgazdasági Szemle, 54. évf. 3. sz. 248-273. o.

SZIR MAI PÉTER-CsAPó KRISZTiÁn [2006]: Gyakorlati vállalkozásoktatás. Diákvállalkozások támogatása a Budapesti Corvinus Egyetemen. Új Pedagógiai Szemle, 56. évf. 4. sz. 72-83. o.

TAвACHNick, B. G.-Fidell, L. S. [2007]: Using multivariate statistics. 5. kiadás. Allyn and Bacon, Boston MA.

Thomas, A. S.-Mueller, S. L. [2000]: A Case for Comparative Entrepreneurship. Assessing the Relevance of Culture. Journal of International Business Studies, Vol. 31. No. 1. 287-301. o. https://doi.org/10.1057/palgrave.jibs.8490906.

Thurik, R.-Dejardin, M. [2012]: Entrepreneurship and Culture. Megjelent: Van Gelderen, M.-Masurel, E. (szerk.): Entrepreneurship in Context- Routledge, Routledge Studies in Entrepreneurship. 175-186. o. https://halshs.archives-ouvertes.fr/halshs-00943684/document.

Wheaton, B.-Muthen, B.-Alwin, D. F.-Summers, G. F. [1977]: Assessing reliability and stability in panel models. Sociological Methodology, Vol. 8. 84-136. o. https://doi. org/10.2307/270754.

Zellweger, T.-Sieger, P.-Halter, F. [2011]: Should I Stay or Should I Go? Career Choice Intentions of Students with Family Business Background. Journal of Business Venturing, Vol. 26. No. 5. 521-536 o. https://doi.org/10.1016/j.jbusvent.2010.04.001.

Zhao, X.-Li, H.-Rauch, A. [2012]: Cross-country Differences in Entrepreneurial Activity: The Role of Cultural Practice and National Wealth. Frontiers of Business Research in China, Vol. 6. No. 4. 447-474. o. https://doi.org/10.3868/s070-001-012-0021-0. 